\title{
Chemical Profile, In Vitro Biological Activity and Comparison of Essential Oils from Fresh and Dried Flowers of Lavandula angustifolia $\mathrm{L}$.
}

\author{
Claudio Caprari, Francesca Fantasma, Fabio Divino (D), Antonio Bucci (D), Maria Iorizzi (D), Gino Naclerio, \\ Giancarlo Ranalli * (D) and Gabriella Saviano*
}

check for updates

Citation: Caprari, C.; Fantasma, F.; Divino, F.; Bucci, A.; Iorizzi, M.; Naclerio, G.; Ranalli, G.; Saviano, G. Chemical Profile, In Vitro Biological Activity and Comparison of Essential Oils from Fresh and Dried Flowers of Lavandula angustifolia $\mathrm{L}$. Molecules 2021, 26, 5317. https://doi.org/ $10.3390 /$ molecules 26175317

Academic Editor: Raffaele Capasso

Received: 29 July 2021

Accepted: 26 August 2021

Published: 1 September 2021

Publisher's Note: MDPI stays neutral with regard to jurisdictional claims in published maps and institutional affiliations.

Copyright: (C) 2021 by the authors. Licensee MDPI, Basel, Switzerland. This article is an open access article distributed under the terms and conditions of the Creative Commons Attribution (CC BY) license (https:// creativecommons.org/licenses/by/ $4.0 /)$.
Department of Bioscience and Territory, University of Molise, C.da Fonte Lappone snc, 86090 Pesche, IS, Italy; claudio.caprari@unimol.it (C.C.); fantasma@unimol.it (F.F.); fabio.divino@unimol.it (F.D.); antonio.bucci@unimol.it (A.B.); iorizzi@unimol.it (M.I.); naclerio@unimol.it (G.N.)

* Correspondence: ranalli@unimol.it (G.R.); saviano@unimol.it (G.S.); Tel.: +39-087-4404-155 (G.R.); +39-087-4404-117 (G.S.)

Abstract: The chemical composition of essential oils (EOs) from dried and fresh flowers of Lavandula angustifolia L. (lavender), named LA 2019 and LA 2020, respectively, grown in central Italy was analyzed and compared by GC and GC-MS. For both samples, 61 compounds were identified, corresponding to $97.9 \%$ and $98.1 \%$ of the total essential oils. Explorative data analysis, performed to compare the statistical composition of the samples, resulted in a high level of global similarity (around 93\%). The compositions of both samples were characterized by 10 major compounds, with a predominance of Linalool (35.3-36.0\%), Borneol (15.6-19.4\%) and 1,8-Cineole (11.0-9.0\%). The in vitro antibacterial activity assay by disk diffusion tests against Bacillus subtilis PY79 and Escherichia coli $\mathrm{DH} 5 \alpha$ showed inhibition of growth in both indicator strains. In addition, plate counts revealed a bactericidal effect on E. coli, which was particularly noticeable when using oil from the fresh lavender flowers at the highest concentrations. An in vitro antifungal assay showed that the EOs inhibited the growth of Sclerotium rolfsii, a phytopathogenic fungus that causes post-harvest diseases in many fruits and vegetables. The antioxidant activity was also assessed using the ABTS free radical scavenging assay, which showed a different antioxidant activity in both EOs. In addition, the potential application of EOs as a green method to control biodeterioration phenomena on an artistic wood painting (XIX century) was evaluated.

Keywords: Lavandula angustifolia L.; GC-MS analysis; essential oil; antibacterial activity; antifungal activity; antioxidant activity; biodeteriogen control

\section{Introduction}

Among the most investigated natural sources of secondary metabolites, aromatic plants play a fundamental role due to their essential oils (EOs) [1-3] and, in the last three decades, there has been a growing interest in their potential use. EOs are variable and complex mixtures of volatile compounds used in the food industry as flavoring agents or for their antibacterial, antifungal and antioxidant properties. The chemical composition of essential oils has a wide range of variability depending on several factors [4]: the geographical area of origin, the environmental and agronomic conditions, the time of harvest, the stage of plant development and the extraction methods [5-10]. All of these parameters can modulate different biological activities.

The Lavandula genus (family Lamiaceae), a small, fragrant shrub native to the Mediterranean area, is cultivated worldwide for its essential oils, which find applications in various industrial areas, such as perfumes, pharmaceutics and cosmetics; furthermore, lavender essential oil is widely used in the food industry because of its biological properties as well as its attractive aroma [5]. It is effective against the growth of a wide range of microorganisms [11,12] and has antioxidant activity [13]. 
The Lavandula genus consists of over 30 species, which display differences in growth habits and morphological characteristics, including leaf shape, arrangement of the flowers and chemical composition. Only three species are principally cultivated to produce essential oils: fine lavender, the most common (Lavandula angustifolia); spike lavender (Lavandula latifolia); and lavandin, a hybrid of the two preceding species. The composition of EOs has been extensively investigated [14] due to commercial interest in aromatherapy (relaxant) and in pharmaceutical preparations for its therapeutic effects as a sedative, spasmolytic, antiviral and antibacterial agent [15]. Lavender EO obtained from L. angustifolia is the most valuable and the most expensive because its yield is lower than the other EOs [16]. The literature data shows that more than 100 components have been identified; the main active ingredients in L. angustifolia flowers' EO are monoterpenes (Linalool, Linalyl acetate, Lavandulol, Geraniol, Bornyl acetate, Borneol, Terpineol and Eucalyptol (also known as 1,8-Cineole), and Lavandulyl acetate) in different percentages according to the geographic area of origin [12]. Lavender EO from Italian regions shows a high concentration of Linalool (ranging from 35 to $36 \%$ ), Linalyl acetate (12 to $21 \%$ ), Camphor (5 to 11\%), 1,8-Cineole (3 to $10 \%)$ and Borneol (2 to $4 \%$ ) [12].

EOs from the Lavandula genus plants exhibit a broad spectrum of biological activities, and antimicrobial activity has been reported for 65 bacterial strains [17-19]. Antimicrobial resistance, and, more specifically, antibiotic resistance in Gram-negative bacteria is a particularly serious public health problem, which poses an urgent need to search for new antibacterial molecules [20]. Escherichia coli is one of the most studied species worldwide and comprises non-pathogenic bacteria that may act as commensals and belong to the normal intestinal microbiota of humans and many animals; its pathogenic variants are divided into diarrheagenic and extraintestinal pathogens [21]. In our study, after a preliminary assessment of the antibacterial activity of lavender oil against two strains of $B$. subtilis and $E$. coli, chosen as representatives of Gram-positive and Gram-negative bacteria, the attention was focused on the latter species because significant levels of microbial contamination can occur during the use of cosmetic products, and the possible presence of pathogenic organisms pose a potential risk to health.

The antifungal activity of the essential oil of L. angustifolia L. was investigated against 50 clinical isolates of Candida albicans, and the EO showed both fungistatic and fungicidal activity [11]. In our study, we evaluated antifungal activity on Sclerotium rolfsii; this is a soil-borne polyphagous phytopathogen fungus that causes Southern blight disease and results in significant crop yield losses worldwide, particularly in tropical and subtropical countries [22].

EOs also have antioxidant properties protecting cells against the harmful impact of free radicals. The antioxidant activity of the $\mathrm{EO}$ of lavender was shown to inhibit effect fat oxidation reactions and lipid peroxidation in a linoleic acid model system [23]. A DPPH assay or an ABTS assay were also considered as simple and sensitive techniques applicable to most essential oils to assess their antioxidant activity [24].

One of the interesting biological activities concerns the administration of lavender EO through inhalation, which seems effective in reducing anxiety levels by having an effect on the central nervous system. [25].

Recently, for controlling biodeteriogens and biocleaning on artworks related to cultural heritage, a great advantage has reported for the application of biomolecules isolated both from marine organisms (Blue Biotechnology) and from plants organisms (Green Technology) [26,27]. With this in mind, lavender's essential oils were tested for their potential use in biological control against microbial contamination on artwork surfaces painted on wood.

This study aimed to determine the chemical composition of the EOs of both dried LA 2019 lavender flowers, stored for one year, and fresh lavender flowers LA 2020. Only a few studies describe the changes in the composition of the EOs during the storage of the dry plant material $[28,29]$, and only one study describes the composition changes due to long-term storage of lavender flowers [30]. 
The purpose of our study was: (i) to compare the chemical composition of dried LA 2019 and fresh LA 2020 flowers; (ii) to submit all data to statistical analyses; (iii) to assess the in vitro antibacterial and the antifungal activities against E. coli, B. subtilis, and the phytopathogenic fungus $S$. rolfsii, respectively; (iv) to evaluate the antioxidant activities of the EOs by ABTS free radical scavenging assay; (v) to test the EOs in the control of biodeteriogens on artworks related to cultural heritage.

\section{Results}

\subsection{Essential Oils Yield and Compositions}

The hydrodistillation of the flowers of L. angustifolia, both LA 2019 and LA 2020, harvested in central Italy (Rosciano, PE) provided an essential oil characterized by a typical smell in a yield of $3.8 \%$ and $3.6 \%$, respectively, calculated according to the initial weight of samples used.

Table 1 reports the chemical composition of the EOs and their experimental retention indices compared with the retention indices reported in the literature [31], their percentage compositions and the abbreviations of the different classes of terpenes; the compounds are listed according to their elution on an $\mathrm{Rtx}^{\circledR}{ }^{\circledR}-5$ Restek capillary column. In this case, 61 compounds were identified, respectively, in samples of both LA 2019 and LA 2020 EOs, corresponding to $97.9 \%$ and $98.1 \%$ of the total area for each sample.

Table 1. Chemical composition of the essential oils (EOs) extracted from the flowers of L. angustifolia.

\begin{tabular}{|c|c|c|c|c|c|c|}
\hline No. & Compound & Exp. RI & Ref. RI & $\begin{array}{c}L A 2019 \text { Area } \\
\% \pm \mathrm{SD}\end{array}$ & $\begin{array}{c}L A 2020 \text { Area } \\
\% \pm \mathrm{SD}\end{array}$ & Abbr. \\
\hline 1 & 2-Methyl-4-pentenal & - & 732 & $0.08 \pm 0.01$ & $0.15 \pm 0.01$ & OT \\
\hline 2 & Santolinatriene & 918 & 908 & $\mathrm{t}$ & $0.01 \pm 0.01$ & $\mathrm{AM}$ \\
\hline 3 & Tricyclene & 922 & 926 & $0.02 \pm 0.00$ & $0.02 \pm 0.00$ & $\mathrm{BM}$ \\
\hline 4 & $\alpha$-Thujene & 929 & 930 & $0.09 \pm 0.01$ & $0.09 \pm 0.01$ & $\mathrm{BM}$ \\
\hline 5 & $\alpha$-Pinene & 936 & 939 & $0.68 \pm 0.02$ & $0.61 \pm 0.01$ & $\mathrm{BM}$ \\
\hline 6 & Camphene & 950 & 954 & $0.51 \pm 0.02$ & $0.61 \pm 0.02$ & $\mathrm{BM}$ \\
\hline 7 & Isothujol & 955 & 960 & $0.04 \pm 0.01$ & $0.05 \pm 0.01$ & $\mathrm{BMO}$ \\
\hline 8 & Heptanol & 965 & 996 & $0.04 \pm 0.01$ & $0.08 \pm 0.02$ & OT \\
\hline 9 & Sabinene & 976 & 975 & $0.20 \pm 0.03$ & $0.15 \pm 0.02$ & $\mathrm{BM}$ \\
\hline 10 & $\beta$-Pinene & 977 & 979 & $0.52 \pm 0.01$ & $0.24 \pm 0.04$ & $\mathrm{BM}$ \\
\hline 11 & 1-Octen-3-ol & 984 & 979 & $0.13 \pm 0.02$ & $0.24 \pm 0.01$ & OT \\
\hline 12 & 3-Octanone & 990 & 983 & $0.17 \pm 0.01$ & $0.16 \pm 0.01$ & OT \\
\hline 13 & Myrcene & 993 & 990 & $0.28 \pm 0.02$ & $0.21 \pm 0.02$ & $\mathrm{AM}$ \\
\hline 14 & Octyn-3-ol & 998 & - & $0.06 \pm 0.01$ & $0.07 \pm 0.02$ & OT \\
\hline 15 & 3-carene & 1009 & 1011 & $0.05 \pm 0.00$ & $0.06 \pm 0.01$ & $\mathrm{BM}$ \\
\hline 16 & 3-Undecen-1-yne & 1018 & - & $0.25 \pm 0.01$ & $0.35 \pm 0.01$ & $\mathrm{AM}$ \\
\hline 17 & p-Cymene & 1026 & 1024 & $0.41 \pm 0.03$ & $0.54 \pm 0.04$ & MM \\
\hline 18 & $R-(+)$-Limonene & 1031 & 1029 & $0.70 \pm 0.05$ & $0.85 \pm 0.05$ & MM \\
\hline 19 & 1,8-Cineole & 1034 & 1031 & $11.0 \pm 0.4$ & $9.0 \pm 0.3$ & $\mathrm{BMO}$ \\
\hline 20 & $(Z)$ - $\beta$-Ocimene & 1043 & 1037 & $0.32 \pm 0.02$ & $0.40 \pm 0.02$ & AM \\
\hline 21 & (E)- $\beta$-Ocimene & 1053 & 1050 & $0.20 \pm 0.01$ & $0.31 \pm 0.02$ & $\mathrm{AM}$ \\
\hline 22 & $\gamma$-Terpinene & 1062 & 1059 & $0.13 \pm 0.01$ & $0.17 \pm 0.00$ & MM \\
\hline 23 & cis-Sabinene hydrate & 1069 & 1070 & $0.57 \pm 0.01$ & $0.50 \pm 0.01$ & $\mathrm{BMO}$ \\
\hline 24 & Linalool oxide cis & 1075 & 1072 & $1.61 \pm 0.04$ & $1.68 \pm 0.04$ & $\mathrm{AMO}$ \\
\hline 25 & Linalool oxide trans & 1089 & 1086 & $1.43 \pm 0.06$ & $1.49 \pm 0.02$ & $\mathrm{AMO}$ \\
\hline 26 & Linalool & 1105 & 1096 & $35.3 \pm 1.0$ & $36.0 \pm 0.1$ & $\mathrm{AMO}$ \\
\hline 27 & $\begin{array}{c}\text { 2,4,6-octatriene, } 3,4 \\
\text { dimethyl }\end{array}$ & 1133 & 1132 & $0.16 \pm 0.02$ & $0.14 \pm 0.04$ & $\mathrm{AM}$ \\
\hline 28 & trans-Pinocarveol & 1142 & 1139 & $0.06 \pm 0.01$ & $0.07 \pm 0.01$ & $\mathrm{BMO}$ \\
\hline 29 & Camphor & 1148 & 1146 & $6.02 \pm 0.04$ & $6.80 \pm 0.07$ & $\mathrm{BMO}$ \\
\hline 30 & n-Hexyliso-butyrate & 1154 & 1150 & $0.33 \pm 0.02$ & $0.30 \pm 0.02$ & $\mathrm{AMO}$ \\
\hline 31 & Borneol & 1170 & 1169 & $15.7 \pm 0.3$ & $19.4 \pm 0.1$ & $\mathrm{BMO}$ \\
\hline 32 & Terpinen-4-ol & 1182 & 1177 & $6.5 \pm 0.1$ & $6.81 \pm 0.02$ & $\mathrm{BMO}$ \\
\hline 33 & Cymen-8-ol & 1189 & 1182 & $0.43 \pm 0.03$ & $0.50 \pm 0.01$ & $\mathrm{MMO}$ \\
\hline
\end{tabular}


Table 1. Cont.

\begin{tabular}{|c|c|c|c|c|c|c|}
\hline No. & Compound & Exp. RI & Ref. RI & $\begin{array}{c}L A 2019 \text { Area } \\
\% \pm \mathrm{SD}\end{array}$ & $\begin{array}{c}L A 2020 \text { Area } \\
\% \pm \mathrm{SD}\end{array}$ & Abbr. \\
\hline 34 & $\alpha$-Terpineol & 1193 & 1188 & $0.88 \pm 0.01$ & $0.51 \pm 0.02$ & $\mathrm{MMO}$ \\
\hline 35 & Hexyl butyrate & 1196 & 1192 & $1.38 \pm 0.04$ & $1.17 \pm 0.02$ & OT \\
\hline 36 & Verbenone & 1212 & 1205 & $0.09 \pm 0.01$ & $0.09 \pm 0.00$ & $\mathrm{BMO}$ \\
\hline 37 & Isobormyl formate & 1231 & 1239 & $0.24 \pm 0.02$ & $0.45 \pm 0.01$ & $\mathrm{BMO}$ \\
\hline 38 & Hexyl-2-metil butyrate & 1242 & 1236 & $0.75 \pm 0.02$ & $0.72 \pm 0.01$ & OT \\
\hline 39 & Hexyl valerate & 1247 & 1244 & $0.27 \pm 0.01$ & $0.28 \pm 0.01$ & OT \\
\hline 40 & Linalyl acetate & 1262 & 1257 & $3.77 \pm 0.08$ & $2.75 \pm 0.02$ & $\mathrm{AMO}$ \\
\hline 41 & Bornyl acetate & 1288 & 1288 & $0.08 \pm 0.01$ & $0.08 \pm 0.00$ & $\mathrm{BMO}$ \\
\hline 42 & Lavandulyl acetate & 1295 & 1290 & $0.70 \pm 0.02$ & $0.63 \pm 0.01$ & $\mathrm{AMO}$ \\
\hline 43 & Carvacrol & 1306 & 1299 & $0.18 \pm 0.01$ & $0.05 \pm 0.01$ & $\mathrm{MMO}$ \\
\hline 44 & Hexyl tiglate & 1336 & 1332 & $0.41 \pm 0.01$ & $0.27 \pm 0.01$ & OT \\
\hline 45 & Terpinyl acetate & 1354 & 1349 & $0.03 \pm 0.01$ & $0.09 \pm 0.00$ & OT \\
\hline 46 & Neryl acetate & 1369 & 1361 & $0.04 \pm 0.01$ & $0.03 \pm 0.01$ & $\mathrm{AMO}$ \\
\hline 47 & Elemene & 1388 & 1390 & $0.07 \pm 0.01$ & $0.07 \pm 0.01$ & MS \\
\hline 48 & Hexyl hexanoate & 1390 & 1383 & $0.30 \pm 0.00$ & $0.30 \pm 0.01$ & $\mathrm{AMO}$ \\
\hline 49 & $\alpha$-Cedrene & 1392 & 1411 & $0.08 \pm 0.01$ & $0.10 \pm 0.00$ & BS \\
\hline 50 & $\alpha$-cis-Bergamotene & 1408 & 1412 & $0.12 \pm 0.01$ & $0.21 \pm 0.01$ & MS \\
\hline 51 & Caryophyllene & 1422 & 1419 & $0.24 \pm 0.01$ & $0.22 \pm 0.01$ & BS \\
\hline 52 & Linalool butanoate & 1428 & 1423 & $0.04 \pm 0.01$ & $0.04 \pm 0.00$ & $\mathrm{AMO}$ \\
\hline 53 & trans-Bergamotene & 1439 & 1434 & $0.06 \pm 0.00$ & $0.06 \pm 0.01$ & MS \\
\hline 54 & Aromadendrene & 1444 & 1441 & $\mathrm{t}$ & $0.04 \pm 0.00$ & BS \\
\hline 55 & $\beta$-Farnesene & 1462 & 1456 & $2.03 \pm 0.04$ & $1.50 \pm 0.01$ & AS \\
\hline 56 & Linalool isovalerate & 1470 & 1468 & $0.09 \pm 0.01$ & $0.07 \pm 0.01$ & ASO \\
\hline 57 & Dodecanol & 1478 & 1470 & $0.35 \pm 0.03$ & - & OT \\
\hline 58 & Lavandulyl isovalerate & 1514 & 1509 & $0.42 \pm 0.03$ & $0.42 \pm 0.04$ & ASO \\
\hline 59 & Spathulenol & 1589 & 1578 & $0.29 \pm 0.01$ & $0.26 \pm 0.01$ & $\mathrm{BSO}$ \\
\hline 60 & Muurolol & 1646 & 1646 & $0.06 \pm 0.01$ & $0.04 \pm 0.00$ & $\mathrm{BSO}$ \\
\hline 61 & Bisabolol oxide B & 1661 & 1658 & $0.12 \pm 0.01$ & $0.08 \pm 0.01$ & BSO \\
\hline 62 & $\alpha$-Bisabolol & 1688 & 1685 & $0.71 \pm 0.02$ & $0.40 \pm 0.00$ & MSO \\
\hline 63 & Tetradecenoic acid & 1696 & - & $0.12 \pm 0.01$ & - & OT \\
\hline
\end{tabular}

Abbreviations: AM: aliphatic monoterpenes; MM: monocyclic monoterpenes; BM: bi-and tricyclic monoterpenes; AMO: aliphatic monoterpenoids; MMO: monocyclic monoterpenoids; BMO: bi-and tricyclic monoterpenoids; AS: aliphatic sesquiterpenes; MS: monocyclic sesquiterpenes; BS: bi- and tricyclic sesquiterpenes; ASO: aliphatic sesquiterpenoids; MSO: monocyclic sesquiterpenoids; BSO: bi- and tricyclic sesquiterpenoids, OT: others. SD: standard deviation; Exp. RI: experimental retention index; Ref. RI: literature data; t: traces.

Qualitatively, the composition of both dried and fresh lavender EOs was quite similar, suggesting an almost total conservation of the components (Figure 1). Only two components in low concentrations (Dodecanol and Tetradecenoic acid) were exclusively present in the LA 2019 sample. Oxygenated monoterpenes represented the most abundant class $(84.30 \%$ and $87.46 \%$ ), followed by monoterpenes $(3.81 \%$ and $3.92 \%)$, sesquiterpenes ( $2.61 \%$ and $2.2 \%$ ) and oxygenated sesquiterpenes (1.69\% and $1.27 \%)$, as shown in Table 2 . Major oxygenated monoterpenes included aliphatic AMO (Linalool 35.3\% and 36.03\% and Linalyl acetate $3.77 \%$ and $2.75 \%$ ) and bicyclic monoterpenes BMO (1,8-Cineole (or Eucalyptol) $11.0 \%$ and $9.0 \%$, Camphor $6.02 \%$ and $6.8 \%$, Borneol $15.67 \%$ and $19.35 \%$, and Terpinen-4-ol $6.51 \%$ and $6.81 \%$ ). None of the monoterpenes exceeded one percent, while only the sesquiterpene $\beta$-Farnesene reached $2.03 \%$ and $1.5 \%$, respectively. 


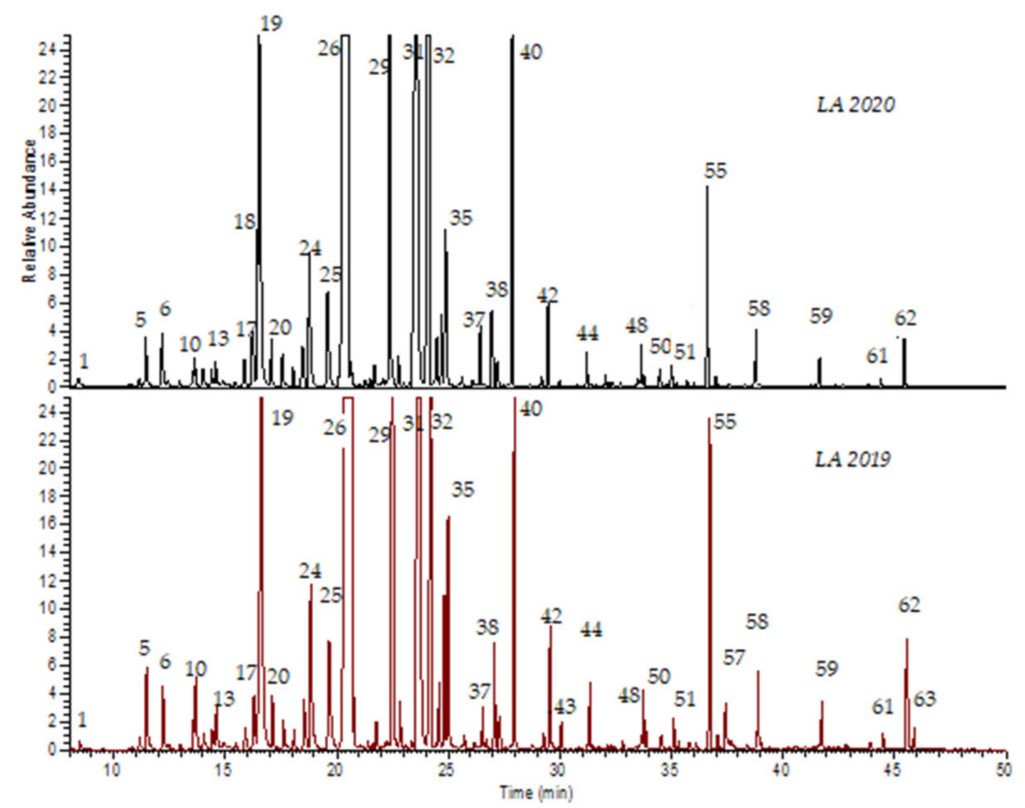

Figure 1. The GC-MS TIC chromatograms of the LA 2019 and LA 2020 samples. Numbers refer to those reported in Table 1.

Table 2. List of terpenes in the lavender oils.

\begin{tabular}{|c|c|c|c|}
\hline & Abbreviation & LA 2019 and Area \% & LA 2020 and Area \% \\
\hline \multirow{3}{*}{$\begin{array}{c}\text { Aliphatic monoterpenes } \\
\text { Monocyclic monoterpenes } \\
\text { Bi-and tricyclic } \\
\text { monoterpenes }\end{array}$} & $\mathrm{AM}$ & 1.2 & 1.42 \\
\hline & MM & 1.24 & 1.56 \\
\hline & $\mathrm{BM}$ & 2.07 & 1.79 \\
\hline Monoterpenes & $\mathbf{M}$ & 3.81 & 3.92 \\
\hline \multirow{3}{*}{$\begin{array}{l}\text { Aliphatic monoterpenoids } \\
\text { Monocyclic monoterpenoids } \\
\text { Bi-and tricyclic } \\
\text { monoterpenoids }\end{array}$} & $\mathrm{AMO}$ & 43.54 & 43.2 \\
\hline & MMO & 1.48 & 1.06 \\
\hline & $\mathrm{BMO}$ & 40.28 & 43.2 \\
\hline Monoterpenoids & MO & 84.30 & 87.46 \\
\hline \multirow{3}{*}{$\begin{array}{l}\text { Aliphatic sesquiterpenes } \\
\text { Monocyclic sesquiterpenes } \\
\text { Bi-and tricyclic } \\
\text { sesquiterpenes }\end{array}$} & AS & 2.03 & 1.5 \\
\hline & MS & 0.26 & 0.34 \\
\hline & BS & 0.32 & 0.36 \\
\hline Sesquiterpenes & $\mathbf{S}$ & 2.61 & 2.2 \\
\hline \multirow{3}{*}{$\begin{array}{c}\text { Aliphatic sesquiterpenoids } \\
\text { Monocyclic sesquiterpenoids } \\
\text { Bi-and tricyclic } \\
\text { sesquiterpenoids }\end{array}$} & ASO & 0.51 & 0.50 \\
\hline & MSO & 0.71 & 0.40 \\
\hline & $\mathrm{BSO}$ & 0.47 & 0.37 \\
\hline Sesquiterpenoids & SO & 1.69 & 1.27 \\
\hline Others & OT & 3.78 & 3.25 \\
\hline
\end{tabular}

Abbreviations: AM: aliphatic monoterpenes; MM: monocyclic monoterpenes; BM: bi-and tricyclic monoterpenes AMO: aliphatic monoterpenoids; MMO: monocyclic monoterpenoids; BMO: bi-and tricyclic monoterpenoids AS: aliphatic sesquiterpenes; MS: monocyclic sesquiterpenes; BS: bi- and tricyclic sesquiterpenes; ASO: aliphatic sesquiterpenoids; MSO: monocyclic sesquiterpenoids; BSO: bi- and tricyclic sesquiterpenoids; OT: others.

\subsection{Explorative Data Analysis}

The data reported in Table 1 are summarized in Figures 2 and 3; the bar plots of the compound percentages, in terms of averages, are reported with the respective standard deviations multiplied by a factor equal to 2 for the LA 2019 and LA 2020 EOs, respectively. 


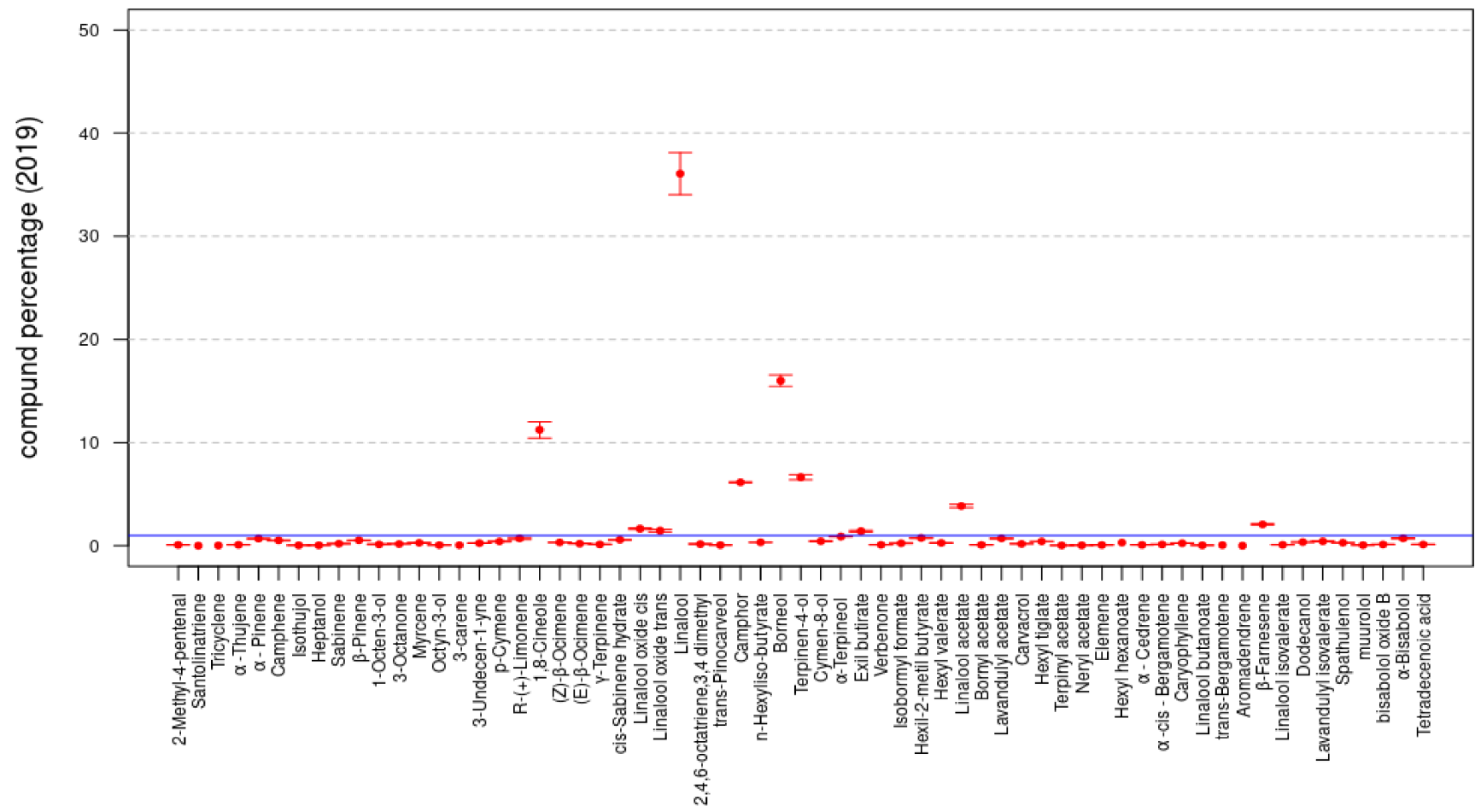

Figure 2. Compound percentages, mean \pm SD, LA 2019 EO.

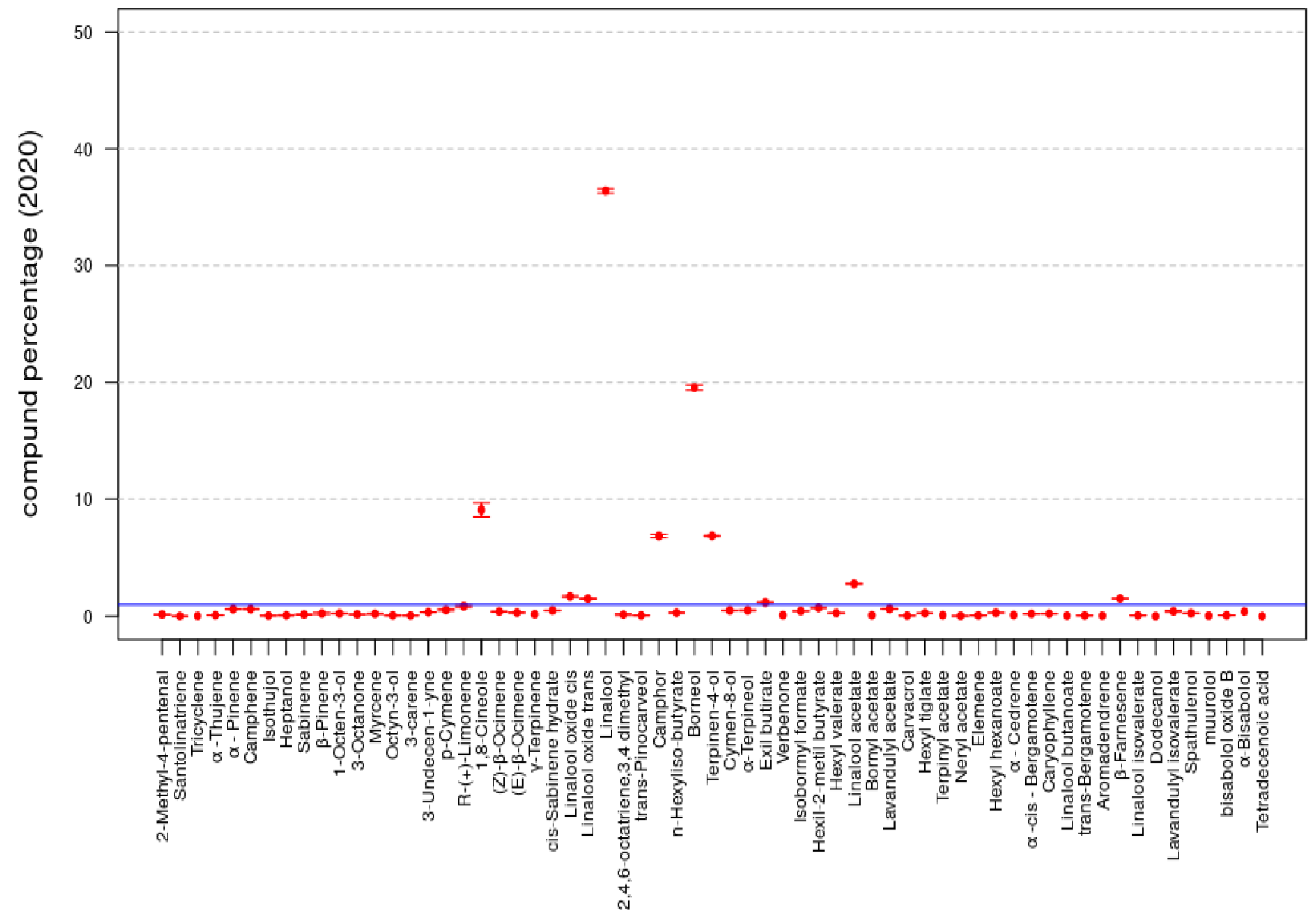

Figure 3. Compound percentages, mean \pm SD, LA 2020 EO. 
In both the LA 2019 and LA 2020 sample data, the statistical compositions of the two samples were rather similar and were characterized by the same set of compounds. For instance, by fixing the threshold to $1 \%$ for both samples, the compounds with presence percentages greater than such a threshold included the following 10 compounds: 1,8Cineole, Linalool oxide cis, Linalool oxide trans, Linalool, Camphor, Borneol, Terpinen-4-ol, Hexyl butyrate, Linalyl acetate and $\beta$-Farnesene.

To compare the compounds of the two samples, the following Figure 4 presents a cross-plot of the two sets of percentages with the 2019 data on the x-axis and the 2020 data on the y-axis. The dashed line represents the situation in which a certain compound was present in the same percentages in both samples. The points distant from the line represent compounds observed in rather different percentages with respect to the two samples. In particular, 1,8-Cineole had a level of $11.0 \%$ in LA 2019 and $9.0 \%$ in LA 2020, and Borneol had levels of $15.7 \%$ and $19.4 \%$, respectively.

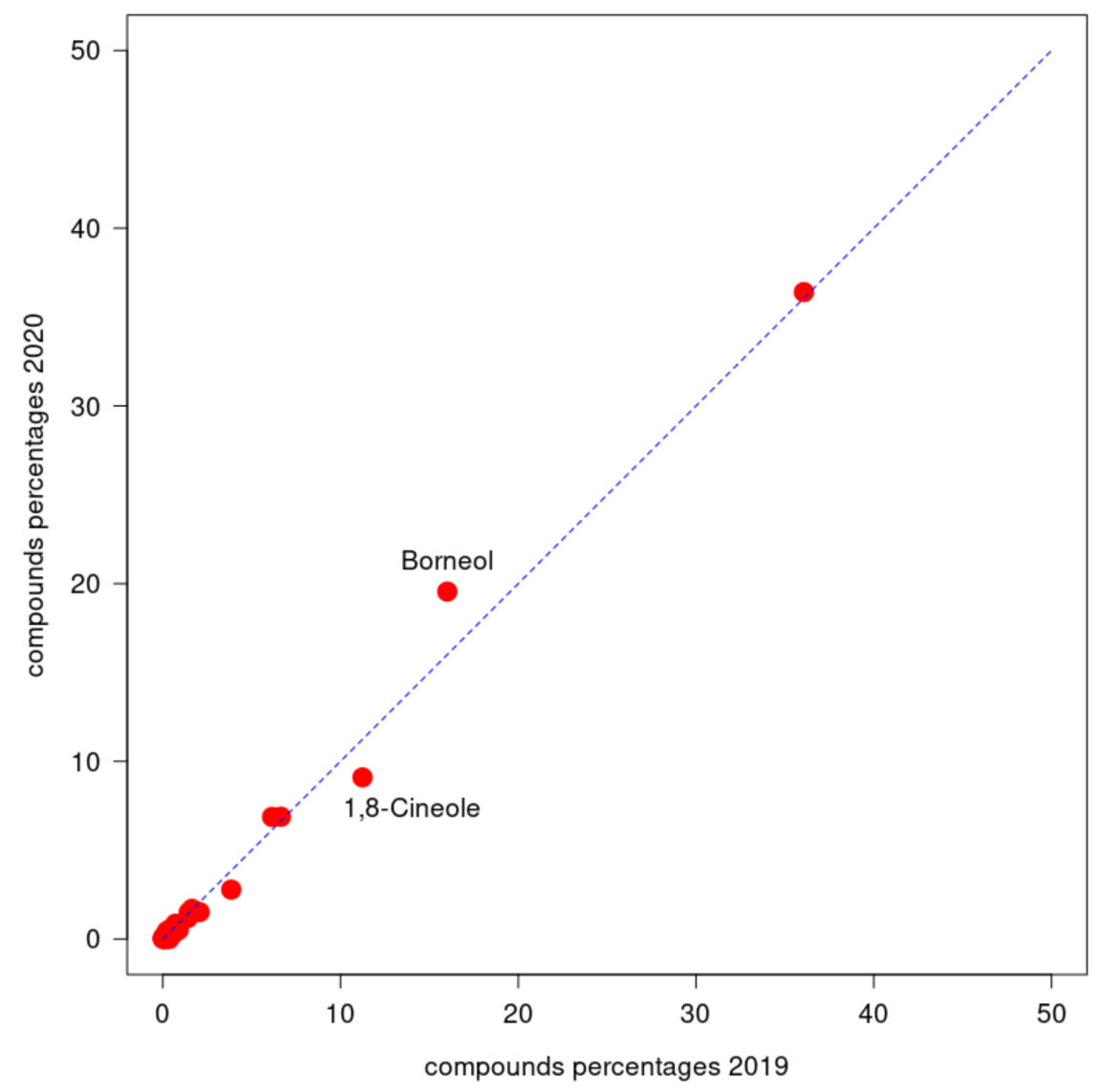

Figure 4. Cross plot of LA 2019 percentages of components vs. LA 2020 percentages of components.

In order to express the level of similarity between the two samples, the percent model affinity (PMA) statistics [32] for the percentages has been calculated:

$$
P M A=100-0.5 \sum_{i=1}^{n}\left|p_{19, i}-p_{20, i}\right|
$$

where $n$ is the number of compounds considered in both samples, while $p_{19}=\left(p_{19,1}, \ldots, p_{19, n}\right)$ and $p_{20}=\left(p_{20,1}, \ldots, p_{20, n}\right)$ are the two sets of percentages, LA 2019 and LA 2020, respectively. The use of $P M A$ statistics is popular in ecology to detect the level of affinity between two samples in terms of species compositions [32]. In this setting, the PMA index was used to compare the LA 2019 composition with the $L A 2020$ one. The value obtained was $P M A=93.61 \%$, confirming a high level of global similarity between the two samples. 
In Figure 5, the bar plot of the absolute differences that contributed to the calculation of the PMA index are reported. The three compounds that showed an absolute difference greater than the threshold of $1 \%$ (line in blue) are highlighted by the name: 1,8-Cineole (11.0\% vs. $9.0 \%$ ), Borneol (15.7\% vs. $19.4 \%$ ) and Linalyl (or Linalool) acetate (3.8\% vs. $2.8 \%$ ). Even though these compounds characterized both the compositions of LA 2019 and $L A 2020$ (as stated previously), the differences between the two samples represented potential and specific features that can distinguish the two types of lavender. However, this aspect needs further investigation.

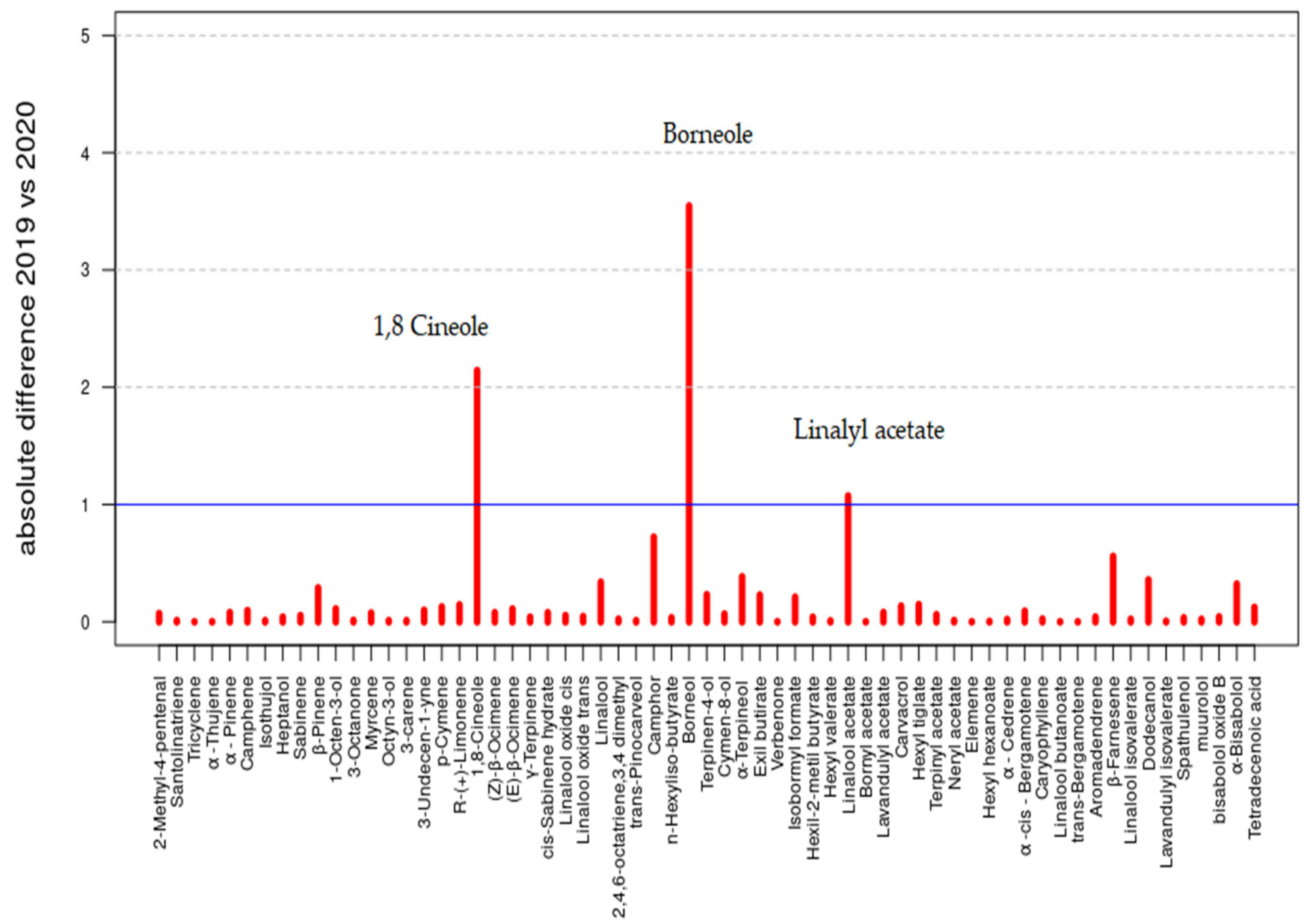

Figure 5. Bar plot of the absolute differences between LA 2019 and LA 2020 percentages.

\subsection{Antibacterial In Vitro Tests}

The results of the disk diffusion test are reported in Figure 6. The LA 2019 and LA 2020 EOs samples showed a noticeable antibacterial activity against E. coli $\mathrm{DH} 5 \alpha$ and $B$. subtilis PY79, with inhibition halos of 20 and $25 \mathrm{~mm}$ in diameter, respectively. To determine whether lavender oil had a bactericidal or a bacteriostatic effect on $E$. coli $\mathrm{DH} 5 \alpha$, various concentrations of lavender oil were added to the indicator strain suspended in PBS buffer. The number of viable bacterial cells was determined by plate counting at various times after the addition of the lavender oil. As shown in Figure 7, the incubation of cells with lavender oil at $25^{\circ} \mathrm{C}$ reduced the number of surviving cells, thus suggesting its bactericidal activity. The effect increased with the increase in lavender oil concentration and the incubation time. Finally, the LA 2020 lavender oil showed a greater bactericidal effect than the LA 2019 lavender oil. 


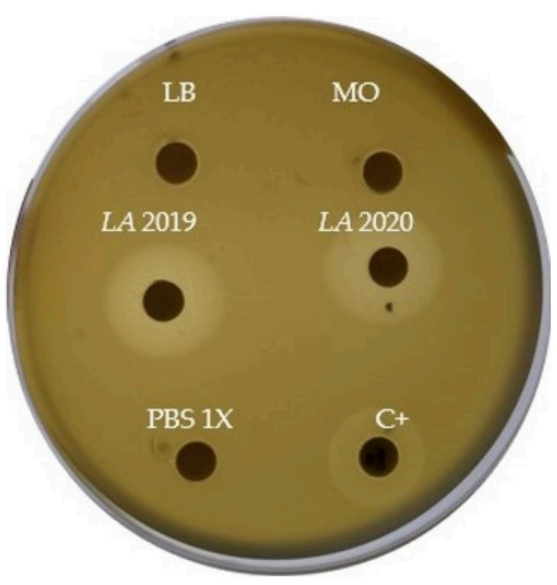

(a)

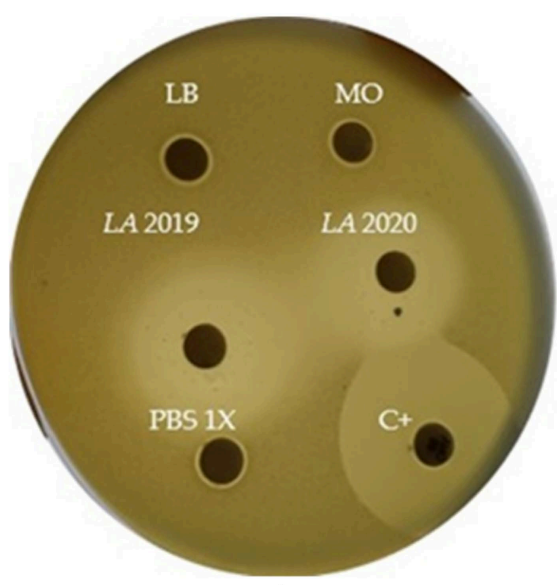

(b)

Figure 6. Zones of growth inhibition (halos) of E. coli DH5 $\alpha$ (a) and B. subtilis PY79 (b) in the presence of $10 \mu \mathrm{L}$ of LA 2019 and LA 2020 EOs. We used $10 \mu \mathrm{L}$ of LB broth (LB), $10 \mu \mathrm{L}$ of mineral oil (MO) and $10 \mu \mathrm{L}$ of PBS $1 \mathrm{X}$ as negative controls, and amoxicillin $(20 \mu \mathrm{g})+$ clavulanic acid $(10 \mu \mathrm{g})$ as positive control $(\mathrm{C}+)$.

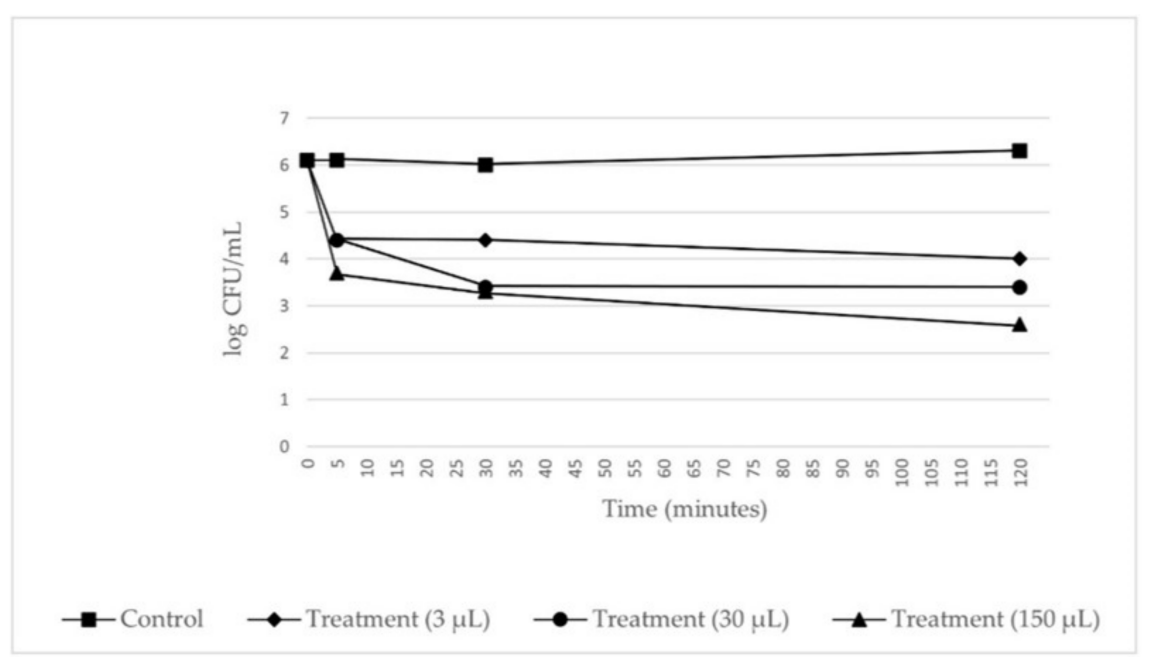

(a)

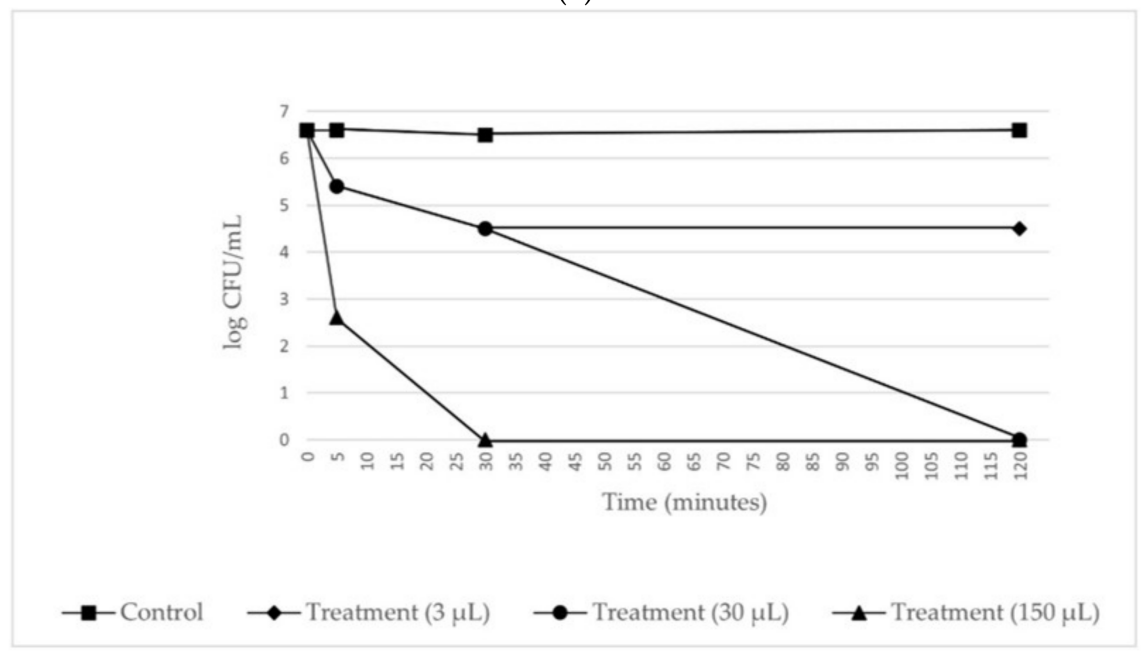

(b)

Figure 7. Effects of different concentrations of LA 2019 EO (a) and LA 2020 EO (b) on the growth of the indicator strain E. coli DH5 $\alpha$. Exponentially growing cells of the indicator strain were incubated with the lavender oils at $25^{\circ} \mathrm{C}$, and samples were tested for growth after various incubation times. 


\subsection{Antifungal In Vitro Test}

S. rolfsii has a wide range of hosts, and it is difficult to clear infested soil; it can survive and thrive in a wide range of environmental conditions and in a wide $\mathrm{pH}$ range [33]. In order to manage rot infection, the development of resistant varieties and the applications of natural extracts such as natural antifungals are considered a more economical and ecological approach than the application of fungicides. In Italy, S. rolfsii is typically present in the Southern regions, but, following hot seasons, infections are occasionally reported in the North as well [34].

The antifungal activity against the growth of $S$. rolfsii phytopathogenic fungus obtained with both LA $2019 \mathrm{EO}$ and LA $2020 \mathrm{EO}$ at different concentrations was evaluated in vitro. Figure 8 reports the reduction of fungal growth, expressed as a reduction in mycelium growth. The results show a concentration-dependent trend where the LA 2020 essential oil was the most effective.

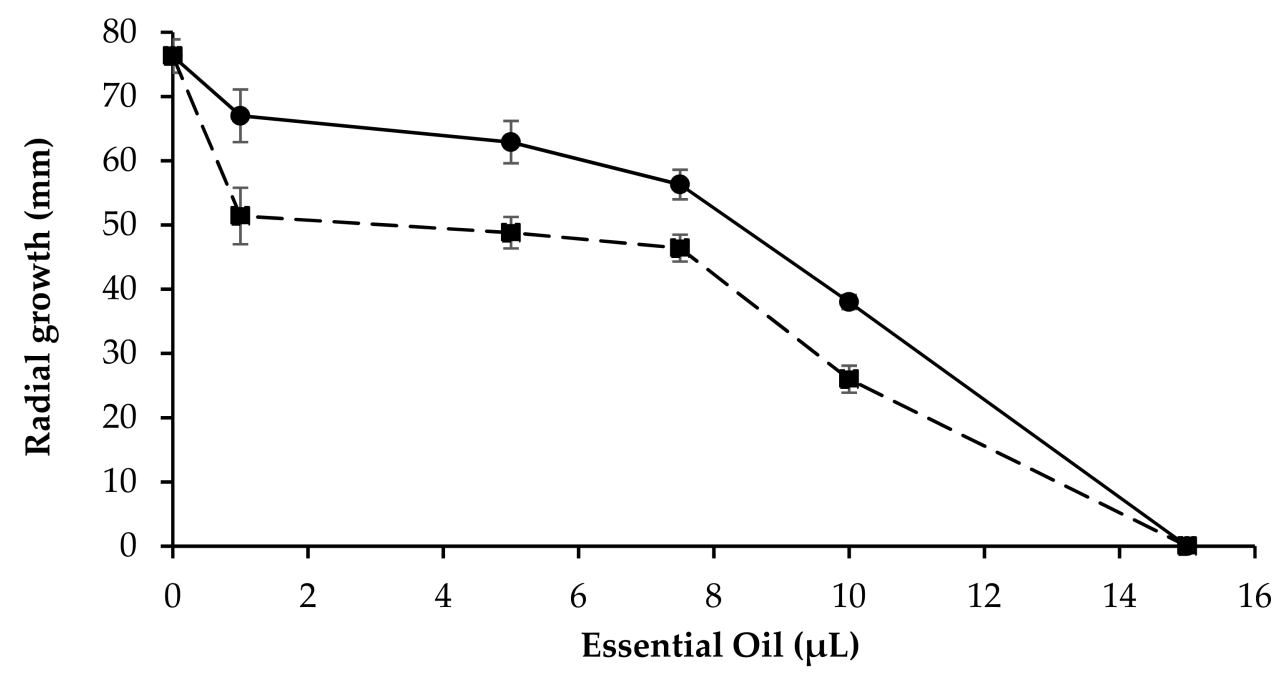

Figure 8. Toxic effect with different concentrations of the $L A 2019(\bullet)$ and $L A 2020(\bullet)$ pure EOs of L. augustifolia on the radial growth of $S$. rolfsii. Tests were conducted in triplicate $\pm \mathrm{SE}$.

The fungal toxic effect was initially slightly decreased in the LA 2019 EO; even at an amount of $15 \mu \mathrm{L}$, neither extract allowed the in vitro growth of the fungal mycelium. The two samples presented only three compounds with significant differences in terms of quantitative composition. This behavior was probably due to the variation of phytochemicals concentration in the analyzed samples. The positive controls for the antifungal activity were carried out using PDA plates added with mancozeb (mancozeb plus $80 \mathrm{WP}$, powder, Manica) at final concentrations in the ranges of $0.025-0.05 \%$ and $0.2-1 \%$. At lower concentrations $(0.025 \%)$, there was a reduction $(30 \%)$ in the mycelial growth of $S$. rolfsii. All other concentrations $(0.05 \%$ and $0.2-1 \%)$ showed a "no growth, mycelium-free" result on the mancozeb PDA plates [34].

\subsection{Antioxidant Test}

The antioxidant properties of LA 2019 and LA 2020 were evaluated. Antioxidant activity was determined using an ABTS radical scavenging assay. This assay is based on the use of a solution containing a radical substance $\left(\mathrm{ABTS}^{\bullet+}\right)$, whose absorbance at $734 \mathrm{~nm}$ decreases in proportion to the amount of antioxidant compounds added. The positive control used in this research was ascorbic acid. The inhibition concentration, $\mathrm{IC}_{50}$, was measured, and the results are listed in Table $3 . \mathrm{IC}_{50}$ was calculated by plotting the $\%$ of inhibition against the concentration in $\mathrm{mg} / \mathrm{mL}$ 
Table 3. Antioxidant activity of L. angustifolia essential oils.

\begin{tabular}{cc}
\hline Samples & IC $_{\mathbf{5 0}}$ ABTS $(\mathbf{m g} / \mathbf{m L})$ \\
\hline LA 2019 & $1.00 \pm 0.07$ \\
LA 2020 & $1.7 \pm 0.1$ \\
Ascorbic acid (positive control) & $0.032 \pm 0.008$ \\
\hline
\end{tabular}

As shown in Figure 9, the inhibition percentage of the free radical increased with the increase in the concentration of the essential oils of lavender. The free radical scavenging activity of both EOs was observed at a concentration of $0.041 \mathrm{mg} / \mathrm{mL}$ to $8.27 \mathrm{mg} / \mathrm{mL}$. The percentage of the inhibition of ABTS from the LA $2019 \mathrm{EO}$ was slightly higher (99.48\%) than that of the LA $2020 \mathrm{EO}(96.88 \%)$.

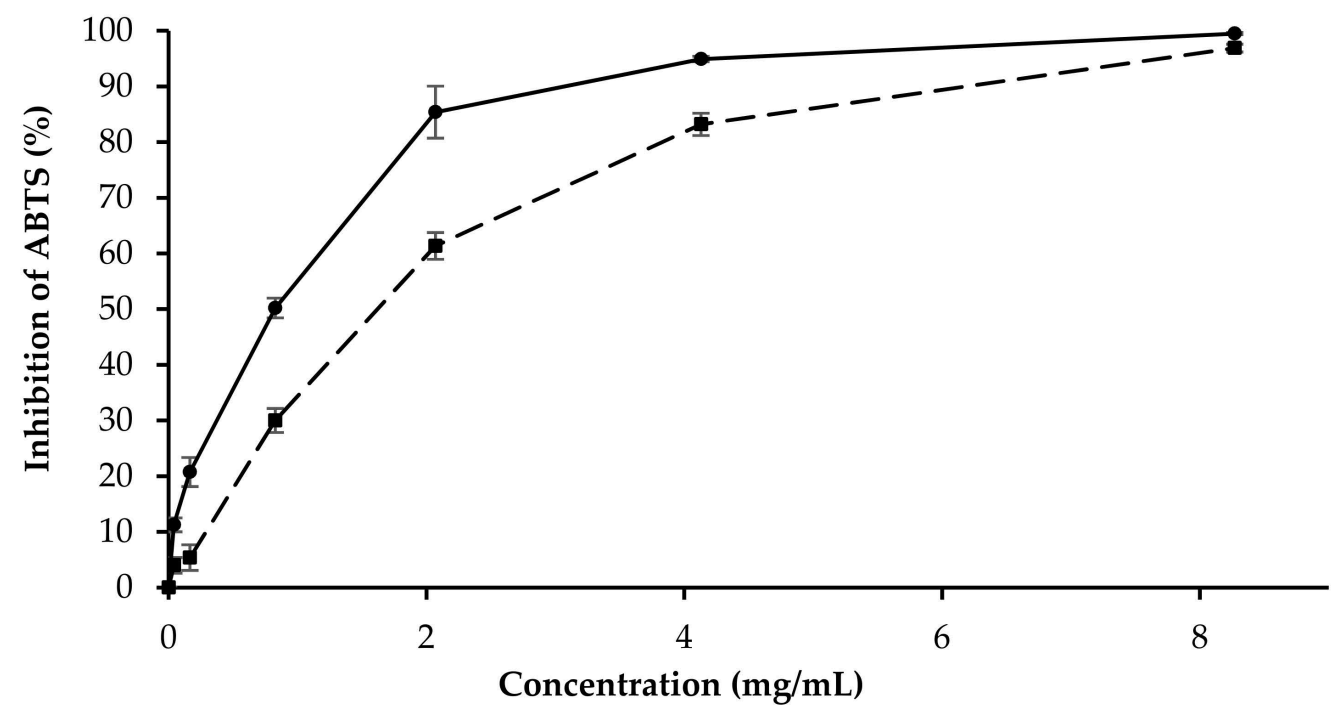

Figure 9. Scavenging effect of the two different essential oils of L. augustifolia, LA 2019 (•) and LA 2020 (•) on ABTS assays at different concentrations ranging from $0.041 \mathrm{mg} / \mathrm{mL}$ to $8.5 \mathrm{mg} / \mathrm{mL}$. Data are expressed as mean values \pm SE $(n=3)$.

\subsection{Biodeteriogen Control on Altered Painting}

In Figure 10a, the total viable microbial count is reported. On the surface of the paint, the total count of viable bacteria ranged from $3 \times 10$ to $2 \times 10^{2} \mathrm{UFC} /$ plate dish after sampling using the sterile velvet technique; the total viable micromycete (fungi) count was less than $5 \times 10 \mathrm{UFC} /$ plate, and there was an absence of yeasts. In Figure 10b, some isolated bacteria yellow pigmented are reported.

After observations, the bacterial strain Micrococcus luteus was identified. In Figure 10c,d, the bacterial growth inhibition by halo diameters underline the effectiveness of the antimicrobial activity of the EOs tested. In fact, the LA 2019 and LA 2020 EO samples showed remarkable differences. The average diameters of the inhibition halos measuring the antimicrobial response (sensible $\geq 6 \mathrm{~mm}$, resistant $<6 \mathrm{~mm}$ ) suggest higher efficacy when LA 2020 was adopted. 


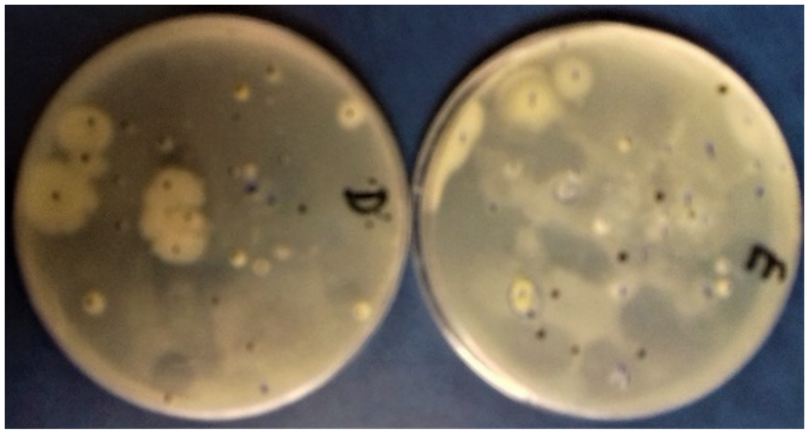

(a)

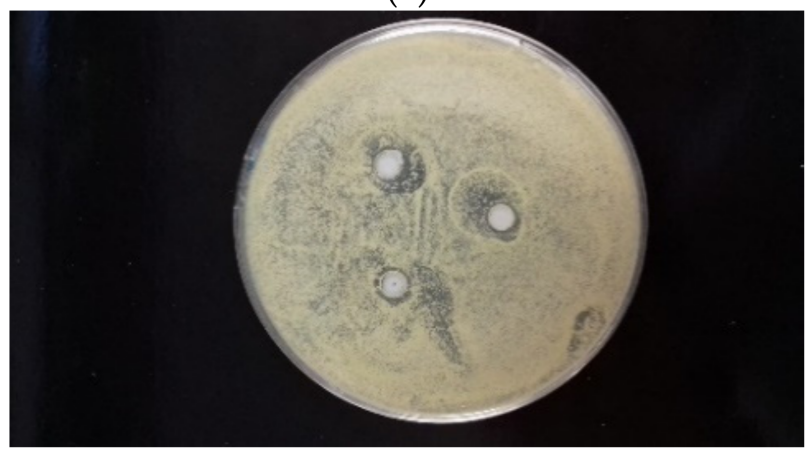

(c)

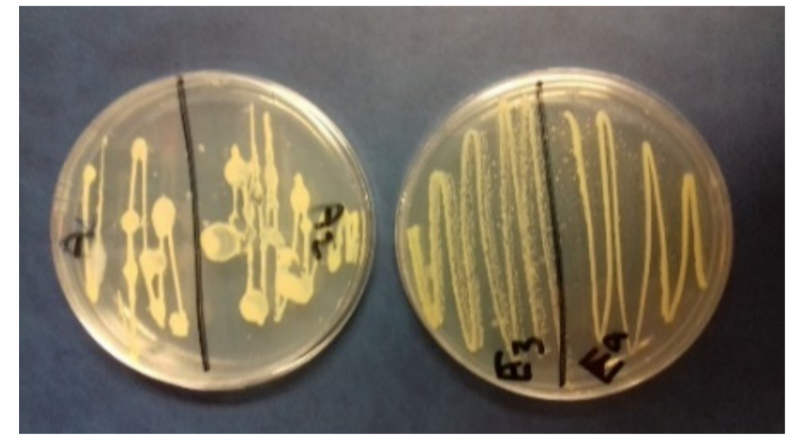

(b)

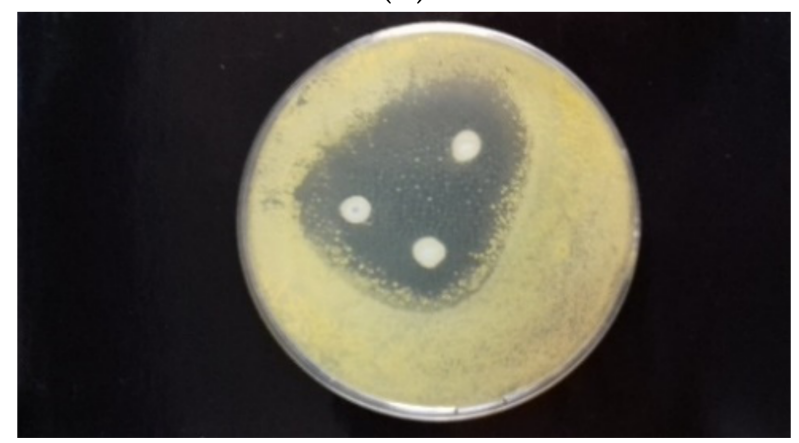

(d)

Figure 10. (a) Microbial growth on agarized cultural medium from paint surface sampled using the sterile velvet technique. (b) Isolation of viable and yellow pigmented bacterial strains, Micrococcus luteus. (c) Antibacterial in vitro test carried out with LA 2019 EO and the absence of antimicrobial effects (halo $<6 \mathrm{~mm}$ ). (d) Antibacterial in vitro test carried out with LA $2020 \mathrm{EO}$ and the presence of antimicrobial effects (halo $>6 \mathrm{~mm}$ ).

\section{Discussion}

Plant metabolites and plant-based pesticides appear to be one of the best alternatives as they have minimal environmental impact and present less hazard to consumers compared to synthetic pesticides. For this purpose, plant extracts and essential oils are ecological, protective, curative and antagonistic to many diseases. Therefore, plant extracts and biological agents can be used as an alternative source to control soil-borne diseases as they are a rich source of bioactive substances [35].

A comparison between L. angustifolia EOs described in the literature highlights the influence of geographic region of origin on the composition and the effective activity or specificity against particular microorganisms [6-10]. Previous studies have indicated that lavender EOs from Italy are rich in Linalool (35-36\%), Linalyl acetate (12-21\%), Camphor $(5-11 \%), 1,8$-Cineole $(3-10 \%)$, Terpinene-4-ol $(2-6 \%), \beta$-Farnesene $(1-4 \%)$ and Borneol $(2-4 \%)$ [12].

In both LA 2019 and LA 2020, the composition of the EOs from L. angustifolia from the Abruzzo region was mainly characterized by a high Borneol content (15.7\% and $19.4 \%)$, Linalool (35.3\% and $36.0 \%$ ) and 1,8-Cineole (11.0\% and 9.0\%), while the concentration of Linalyl acetate (3.77\% and $2.75 \%$ ) was low. In the fresh sample $L A 2020$, a high concentration of Borneol and Linalool was associated with a low concentration of 1,8-Cineole (9\%); in the dried sample $L A 2019$, the level of Linalool and Borneol slightly decreased, while the level of 1,8 Cineol (11\%) increased.

It should be noted that a high concentration of Borneol (22.6\%), associated with a high level of 1,8-Cineole (39.8\%) and Camphor (22.1\%), has previously been observed only in the EO of L. angustifolia obtained from leaves and stem grown in Brazil, which showed anti-inflammatory activity. [36]. The relatively small amount of Linalyl acetate in respect to the literature data can be attributed to partial decomposition during hydrodistillation [13]. Most of these components belong to the alcohol group, and, among them, linalool was 
demonstrated to be the strongest active ingredient against a wide range of microorganisms [37]. The antibacterial activity of 33 free terpenes commonly found in essential oils was recently investigated [38]. It was demonstrated that Borneol, in both enantiomeric forms, exhibited antimicrobial activity against B. cereus, E. coli and S. aureus (MIC ranging from 0.03 to $0.25 \mathrm{mg} / \mathrm{mL}$ ) and S. typhimurium (MIC 0.12 to $800 \mathrm{mg} / \mathrm{mL}$ ). Similar antibacterial activity was found for $( \pm$ ) Linalool (MIC $0.25 \mathrm{mg} / \mathrm{mL}$ ), while 1,8-Cineole was inactive against all strains tested [38].

It is known that the synergistic or antagonistic effects of the chemical components in the EOs can contribute to the difference in the biological activities [39]; however, as both our LA 2019 and LA 2020 samples contained a large amount of Linalool and Borneol, we can assume that the antibacterial and antifungal activity was in part influenced by the concentration of these components. Indeed, the higher concentration of Linalool (36.0\%) and Borneol (19.4\%) in the fresh lavender sample (LA 2020) resulted in higher antimicrobial activity than the same activities observed in the dried lavender sample (LA2019). Borneol in elevated concentrations may be considered as marker component of Lavandula genus from the Abruzzo region, and this is probably related to the local microhabitat in which L. angustifolia is cultivated (see Plant Material). This particular chemical composition is reported here for the first time.

The composition of the EOs may explain the different values of $\mathrm{IC}_{50}$ in the antioxidant test. The high content of monoterpenes and monoterpenoids may be responsible for the antioxidant activity. The higher antioxidant activity of LA 2019 EO could be related to the synergistic property associated with the high content of sesquiterpenes and their derivatives (Table 2) [40].

The preliminary results of the antibacterial assays on B. subtilis PY79 and, specifically, on E. coli DH5 $\alpha$ cells are encouraging and set the stage for further research focused on clinically relevant bacterial species. Antimicrobial resistance in bacteria, especially resistance in Gram-negative bacteria, is concerning. This complex and relatively old phenomenon is the consequence of the vertiginous decrease in research and the development of new antibacterial compounds and the appearance and spread of resistant or even multidrugresistant bacteria [20]. Accordingly, one of the priorities of research should be the search for new antibacterial molecules since the therapeutic arsenal is shrinking and there is a lack of new molecules with new chemical structures or new mechanisms of action to fight the Gram-negative bacteria that currently pose the greatest threat to human health. Antibacterial activity assays against $E$. coli $\mathrm{DH} 5 \alpha$ revealed a bactericidal effect that was particularly noticeable when using oil from fresh lavender flowers at the highest concentrations $(30 \mu \mathrm{L}$ and $150 \mu \mathrm{L}$ ). It is likely that the stronger impact observed after testing the $L A 2020 \mathrm{EO}$ at the highest concentrations could also be due to those compounds characterizing potential and specific features of the investigated oil samples.

The metabolic functions of microorganisms can be altered by gaseous contact and exposure to essential oils. One study reports that vapor levels of $0.1-0.9 \mathrm{mg} / \mathrm{L}$ in air may suppress the growth of the bacterial pathogens responsible for respiratory infections [41]. Several EOs, such as those from cinnamon bark, lemongrass and thyme, have been shown to be the most effective in this field. Antimicrobial and antiseptic properties and antiviral activity have been studied in eucalyptus oils and tea tree oil (Melaleuca alternifolia) [42-44], and their use as disinfectants for indoor air quality after adequate development of air technologies has been suggested $[45,46]$.

Antifungal activity was performed in vitro with the pathogen S. rolfsii Sacc. (teleomorph Athelia rolfsii (Curzi) C. C. Tu and Kimbr.), which is considered one of the most destructive pathogens worldwide, characterized by wide host range comprising more than 500 plant species from 100 families, including tomatoes, potatoes, chili peppers, carrots, cabbage, sweet potatoes, common beans and ground nuts [47,48]. S. rolfsii, a polyphagous pathogenic fungus and infects a very large number of plant species of agricultural interest with a mortality ranging from 10 to $100 \%$ [49]. Due to the abundant production of sclerotia that can persist in the soil for years, the management of the pathogen can be achieved 
with various fungicides, soil fumigants (methyl bromide), plant extracts and biological agents [35].

Essentially, the LA 2019 and LA 2020 Eos were both active against the fungus, but the fungal toxic effect was slightly greater with $L A 2020$ than $L A$ 2019. Our results suggest that the greater antifungal activity of $L A 2020$ can be related to the higher concentration of Borneol, and the synergistic or antagonistic effects of other compounds, as reported, can amplify its antifungal activity [39]. Some mechanisms have been proposed, such as the possibility that terpenes can increase the concentration of lipid peroxides and cause cell death [50], or that they can act on the hyphae of the mycelium, inducing the release of components from the cytoplasm and hence the death of the mycelium [51].

A current and relevant problem in the field of cultural heritage is the conservation of wooden paintings, which are potentially attacked by microorganisms and pests over the years. Preliminary results need confirmation from extensive antibacterial tests on both isolated microbes and the complex microbial community of the altered artwork.

In the case of antibacterial and antifungal testing, we need an in-depth study that includes more strains of both bacteria and fungi (both resistant and sensitive strains where possible) to definitively conclude the antibacterial and antifungal activities of these EOs. Moreover, further research will explore the cytotoxicity of the EOs to support the final correct operative decisions.

These indications, if functional and supported by solid statistical analyses, could be useful to develop a new organic green strategy for the recovery of altered works of art and as an alternative to the use of biocides and toxic compounds.

From these perspectives, the use of L. angustifolia EOs as a natural essence in a confined space, such as a bag containing the work of art needing restoration, for an adequate amount of time, could be a suitable technical solution.

\section{Materials and Methods}

\subsection{Plant Materials}

L. angustifolia flowers were collected in September 2019 and September 2020, always in the early hours of the morning by the same staff. The flowers were harvested from the same shrubs in the same area during the balsamic period, at Villa Vanda Farm $\left(42^{\circ} 20^{\prime} 59.83^{\prime \prime} \mathrm{N}\right.$, $\left.14^{\circ} 01^{\prime} 54.88^{\prime \prime} \mathrm{E}\right)$ at an altitude of about $150 \mathrm{~m}$ and at a distance of $20 \mathrm{~km}$ from the Adriatic Sea. The flowers are grown in parallel rows and in association with a centuries-old olive groves managed according to the rules of organic farming in an area called "Oasi orientale di Villa Badessa", Rosciano (Pe, Abruzzo Region, Italy).

The soil has a predominantly loamy-clayey texture with no summer irrigation. The plant was identified by Dr. Fortini, and a voucher specimen was deposited in the Herbarium of DiBT, University of Molise. The flowers harvested in 2019 were well preserved for one year in the dark at room temperature $\left(21^{\circ} \mathrm{C}\right)$ and were then submitted to hydrodistillation to give the EO (named dried LA 2019). The flowers harvested in 2020 were immediately used for the hydrodistillation of the EO (named fresh LA 2020). The composition of both samples was analyzed and compared.

\subsection{Essential Oil Isolation}

Defined amounts of flowers (200 g) both of dried (2019) and fresh (2020) L. angustifolia were hand selected and cleaned, and then separately subjected to hydrodistillation for $3 \mathrm{~h}$ according to the standard procedure described in the Council of Europe [52]. The essential oils were dried over anhydrous sodium sulfate to remove traces of water and then stored in dark vials at $4{ }^{\circ} \mathrm{C}$ prior to gas chromatography-mass spectrometry (GC-MS) analysis.

\subsection{GC-FID Analysis}

The characterization of both essential oils samples was determined with a gas chromatography system GC 86.10 Expander (Dani) equipped with an FID detector, Rtx ${ }^{\circledR}-5$ Restek capillary column ( $30 \mathrm{~m} \times 0.25 \mathrm{~mm}$ i.d., $0.25 \mu \mathrm{m}$ film thickness) (diphenyl-dimethyl 
polysiloxane), a spilt/splitless injector heated to $250{ }^{\circ} \mathrm{C}$ and a flame ionization detector (FID) heated to $280^{\circ} \mathrm{C}$. The column temperature was maintained at $40^{\circ} \mathrm{C}$ for $5 \mathrm{~min}$, then programmed to increase to $250{ }^{\circ} \mathrm{C}$ at a rate of $3{ }^{\circ} \mathrm{C} / \mathrm{min}$ and held, using an isothermal process, for $10 \mathrm{~min}$; the carrier gas was $\mathrm{He}(1.0 \mathrm{~mL} / \mathrm{min}) ; 1 \mu \mathrm{L}$ of each sample was dissolved in $n$-exane (1:500 $n$-exane solution) and injected. The experiment was repeated three times.

\subsection{GC/MS Analysis}

The GC-MS analyses were performed on a Trace GC Ultra (Thermo Fisher Scientific) gas chromatography instrument equipped with a Rtx ${ }^{\circledR}-5$ Restek capillary column (30 m $\times$ $0.25 \mathrm{~mm}$ i.d., $0.25 \mu \mathrm{m}$ film thickness) and coupled with an ion-trap (IT) mass spectrometry (MS) detector Polaris Q (Thermo Fisher Scientific, Waltham, MA, USA).

A Programmed Temperature Vaporizer (PTV) injector and a PC with a chromatography station Xcalibur (Thermo Fisher Scientific) was used. The ionization voltage was $70 \mathrm{eV}$; the source temperature was $250^{\circ} \mathrm{C}$; full scan acquisition in positive chemical ionization was from $m / z 40$ up to 400 a.m.u. at 0.43 scan s$^{-1}$. The GC conditions were the same as those described above for the gas chromatography (GC-FID) analysis.

\subsection{Identification of Essential Oil Components}

The identification of the essential oil components was based on the comparison of their Kovats retention indices (RIs) and RI (linear retention indices), determined in relation to the $\mathrm{t} R$ values of a homologous series of $n$-alkanes (C8-C20) injected under the same operating conditions as those described in the literature [53,54].

The MS fragmentation patterns of a single compound were those from the NIST 02 , Adams and Wiley 275 mass spectral libraries [55,56]. The relative contents (\%) of the sample components were computed as the average of the GC peak areas obtained in triplicate without any corrections [57].

\subsection{Statistical Analysis}

The explorative data analysis was performed using $\mathrm{R}$ software, available as free software under the terms of the Free Software Foundation's GNU General Public License in source code form.

\subsection{Antibacterial Activity Assays against B. subtilis PY79 and E. coli DH5 $\alpha$}

As a preliminary step, the antibacterial properties of lavender oil against $B$. subtilis PY79 and E. coli DH5 $\alpha$ cells were determined using the paper disk diffusion method. Sterile paper disks $6 \mathrm{~mm}$ in diameter were placed onto Luria-Bertani (LB) agar plates, previously inoculated with $150 \mu \mathrm{L}$ of B. subtilis PY79 [58] or E. coli DH5 $\alpha$ [59] cultures grown in LB broth at $37{ }^{\circ} \mathrm{C}$, with agitation at $120 \mathrm{rpm}$ until an optical density (OD) at $600 \mathrm{~nm}$ of 1.0 was achieved. Then, the disks were impregnated with $10 \mu \mathrm{L}$ of the essential oil samples LA 2019 and LA 2020. Disks with PBS 1X, LB broth and mineral oil were used as negative controls, whereas a disk containing amoxicillin $(20 \mu \mathrm{g})+$ clavulanic acid $(10 \mu \mathrm{g})$ was used as a positive control. The plates were incubated at $37^{\circ} \mathrm{C}$ for $24 \mathrm{~h}$, and the diameter of inhibitory zones was measured. The experiment was repeated three times. Afterwards, in order to assess if the EOs had a bactericidal or a bacteriostatic effect on E. coli DH5 $\alpha$, various volumes $(3,30$ and $150 \mu \mathrm{L})$ of lavender oil were added to $\approx 10^{7}$ cells re-suspended in PBS 1X, for a final volume of $300 \mu \mathrm{L}$. Viable counts were performed at different times from the exposure $(5,30$ and $120 \mathrm{~min})$. The experiment was repeated three times.

\subsection{Antifungal Activity Assay}

The mold strain of $S$. rolfsii, previously identified and characterized [34], was used in this study. Pure essential oils from the two LA 2019 and LA 2020 samples were dissolved in a final volume of $200 \mu \mathrm{L}$ in ethanol and then added to $19 \mathrm{~mL}$ PDA plates to obtain the different final concentrations. Mycelial plugs ( $4 \mathrm{~mm}$ in diameter) from the edges of the S. rolfsii 5-day culture were incubated in the center of each PDA plate ( $90 \mathrm{~mm}$ diameter). 
The fungal cultures were incubated in the dark at $27^{\circ} \mathrm{C}$ and $70 \%$ relative humidity (RH) for 3 days. The tests were conducted in triplicate. The antifungal activity was determined by measuring the diameter (in $\mathrm{mm}$ ) of radial growth. The control growth was carried out on PDA plates prepared as described above, but without the EO samples. The positive controls for the antifungal activity were carried out using PDA plates added with mancozeb (Mancozeb plus $80 \mathrm{WP}$, powder, Manica SpA, Rovereto, Italy) at final concentrations in the range of $0.025-0.05 \%$ and $0.2-1 \%$. The growth of the S. rolfsii mycelia control was monitored on the PDA plates at $27^{\circ} \mathrm{C}$ and $70 \%$ relative humidity (RH) for 3 days.

\subsection{Antioxidant Activity}

The ABTS method was used based on the ability of antioxidant molecules to quench the long-lived $\mathrm{ABTS}^{\bullet+}$. The ABTS ${ }^{\bullet+}$ was generated by peroxydisulfate oxidation $2,2^{\prime}$ azinobis (3-ethylbenzothiazoline-6-sulfonic acid) following the reported method with minor changes [39]. Briefly, the ABTS ${ }^{\bullet+}$ solution was prepared by mixing $5 \mathrm{~mL}$ of a $7 \mathrm{mM}$ solution of ABTS in water with $88 \mu \mathrm{L}$ of a $140 \mathrm{mM}$ solution of potassium persulfate. The solution was stored at room temperature $16 \mathrm{~h}$ in the dark. The working solution was prepared by adding methanol until the absorbance was large $(0.70 \pm 0.001)$ at $734 \mathrm{~nm}$. The samples were prepared by mixing different volumes of EOs (ranging from 0.05 to $20 \mu \mathrm{L}$ ) in $100 \mu \mathrm{L}$ of $70 \%$ final methanol solution. The control contained only $70 \%$ methanol in water. A volume of $1 \mathrm{~mL}$ of working solution was mixed with $100 \mu \mathrm{L}$ of samples and incubated for $4 \mathrm{~min}$ at room temperature. After incubation, the absorbance of the reaction mixture was measured at $734 \mathrm{~nm}$. The experiment was performed in triplicate. The ability of the essential oil to scavenge ABTS radicals was calculated as \% inhibition by the following Equation: \% inhibition $=[($ Abs control - Abs sample $) /($ Abs control $)] \times 100$, where Abs control is the absorbance of the $\mathrm{ABTS}^{\bullet+}+$ methanol; Abs sample is the absorbance of $\mathrm{ABTS}^{\bullet+}+\mathrm{EO}$. Ascorbic acid was used as a standard.

\subsection{Case Study: A Painting on Wood Dated from the XIX Century}

A historical wood painting was chosen for the ex situ study "Madonna con Bambino", originally located on the inner wall of the S. Maria del Lago church at Pesche (Isernia, Italy), Figure 11a. The artwork $(140 \mathrm{~cm} \times 55 \mathrm{~cm} \times 3.5 \mathrm{~cm})$ painted by an anonymous painter was submitted to microbiological sampling on the basis of aesthetical alterations on the surface of the paint after preliminary observation by R. Sartorio Restorer (Uraniarst, Isernia, Italy), commissioned by the Bishop in charge at the Cathedral-Bishop's Curia, Isernia. The water painting was irregularly affected by very small lacunas, visible even to the naked eye, only in some areas on the paint's surface.

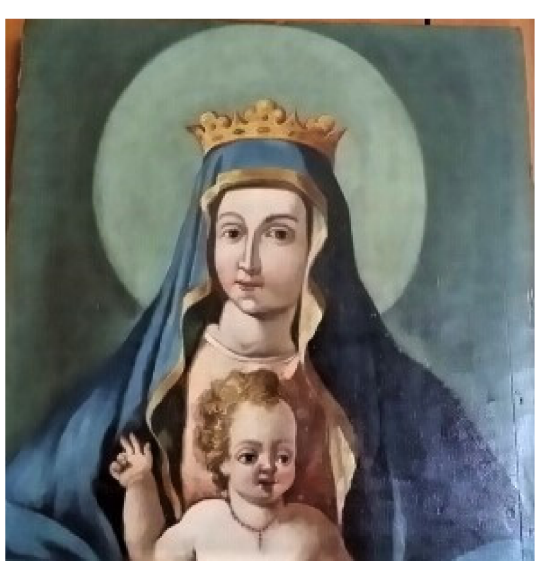

(a)

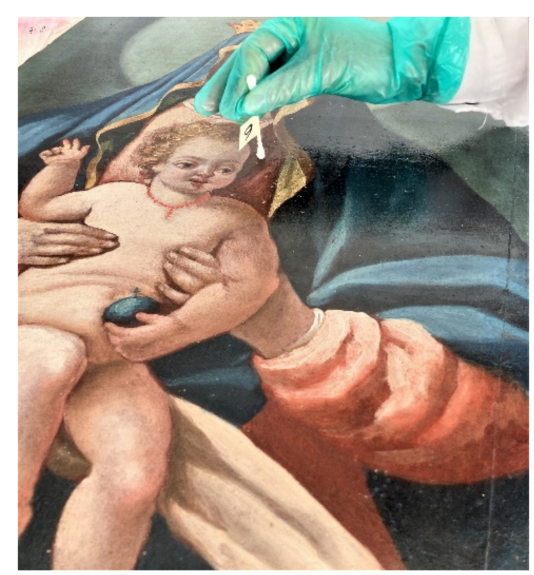

(b)

Figure 11. (a) Historical wood paintings, "Madonna con Bambino", originally located in the Santa Maria del Lago church, chosen for the ex situ study. (b) Sampling phase used sterile cotton swabs for microbiological analyses, with permission of the Bishop in charge of the Cathedral-Bishop's Curia, Isernia. 
Microbiological analyses were carried out as follows: (i) sampling by soft and nondestructive techniques using sterile cotton swabs and sterile velvet tampons (Figure 11b); (ii) the inoculation of the samples on sterile Petri dishes containing cultural solid media for the growth of total aerobic bacteria (Standard Plate Count Agar, Difco; incubation at $37^{\circ} \mathrm{C}$ for 48-72 h); for the total micromycetes (fungi and yeasts, Peptone Destrosio Agar Rosa Bengala, Dif(o), the incubation was at $28^{\circ} \mathrm{C}$ for $48 \mathrm{~h}$.

\subsection{Antimicrobial Activity on Paint}

The antimicrobial activities (antagonistic properties) of the isolated bacteria were evaluated in vitro using the EO diffusion agarized nutrient method. Only the yellowpigmented bacterial strains typically representative of biological particulates both in the air environment and the surface of the potential biodeteriorated paint were identified. The tests included morphological properties under microscopic observations and physiological and biochemical tests by a Gram reaction and Api-Systems (Biomerieux Italia, Firenze) according to Bergey's Manual [60].

For the assay against yellow-pigmented isolated bacteria, the L. angustifolia EOs were tested using both agar wells and disk diffusion on Petri dishes containing Plate Count Agar (PCA, Difco) and inoculation of selected strains. The suspensions containing exponentially growing bacteria after an overnight broth culture, at approximately $10^{8} \mathrm{CFU} / \mathrm{mL}$, corresponding to an O.D. $560 \mathrm{~nm}$ of approximately 1.6, were used [61,62].

Paper disks with EO microdilution $(10 \mu \mathrm{L} /$ disk) were carried out in triplicate. As a control, a sterile physiological solution instead of EO dilutions were adopted. The plates were incubated at $37^{\circ} \mathrm{C}$ for $48-72 \mathrm{~h}$, and the halos of inhibition around the disks were measured (in $\mathrm{mm}$ ).

\section{Conclusions}

In the present study, a relationship between the composition of fresh and dried EOs of flowers extracted from L. angustifolia and the antimicrobial and antioxidant activity was observed. The two samples (LA 2019 and LA 2020) were qualitatively similar and contained Borneol and Linalool in high concentrations. This is the first time that an EO from L. angustifolia with a high Borneol content has been described in Italy. The differences observed between the two samples (dried and fresh lavender) concerned only the concentration of Borneol, Linalool and 1,8-Cineole, suggesting an almost total conservation of the components during the drying process. In our experimental conditions, we presumed that the antibacterial and antifungal activity was partially influenced by the concentration of these components.

The Borneol-rich oils harvested in central Italy were found to have antibacterial activity against both B. subtilis PY79 and E. coli DH5 $\alpha$, with a significant bactericidal effect on the latter as well as an antifungal effect on the phytopathogen fungus $S$. rolfisii. These activities are associated with a scavenging capacity; therefore, our results suggest that the EO can be used as potential biopreservatives in several fields by reducing and inhibiting pathogenic bacteria. Their antioxidant activity makes L. angustifolia EOs a favorable candidate for decreasing the level of microbial contamination not only in different categories such as cosmetic products (lipstick, beauty creams, etc.) but also in potential "natural" alternatives to synthetic antioxidants/bactericides.

The interesting antimicrobial activities, if confirmed with further studies on the biodeteriogen microflora associated with the artworks, could be useful in establishing a new green biological strategy for the recovery of altered artworks and as an alternative to the use of biocides and toxic compounds.

Author Contributions: Conceptualization, G.S., F.F. and C.C.; methodology, investigation and data curation, A.B., C.C., F.D., F.F., M.I., G.N., G.R. and G.S.; software, F.D.; writing-original draft preparation, writing-review and editing, C.C., M.I., G.R. and G.S.; supervision, M.I. and G.R. All authors have read and agreed to the published version of the manuscript. 
Funding: This research received internal funding from the University of Molise, titled Characterization and activity of plant compounds and extracts, years 2018-2020. DIBT 308/18.

Institutional Review Board Statement: Not applicable for studies not involving humans or animals.

Informed Consent Statement: Not applicable for studies not involving humans.

Acknowledgments: The authors would like to acknowledge the Bishop in charge at the CathedralBishop's Curia, Isernia, for the authorization to carry out studies on the altered work of art; R. Sartorio Restorer (Uraniarst, Isernia) for technical support in the microbial monitoring and, finally, P. Fortini as the Director of Museo delle Scienze Naturali del Molise (MuSNaM), DiBT, University of Molise.

Conflicts of Interest: The authors declare no conflict of interest.

Sample Availability: Samples of the compounds are available from the corresponding authors.

\section{References}

1. Petrovska, B.B. Historical review of medicinal plant usage. Pharmacogn. Rev. 2012, 6, 1-5. [CrossRef]

2. Smeriglio, A.; Trombetta, D.; Cornara, L.; Valussi, M.; De Feo, V.; Caputo, L. Characterization and phytotoxicity assessment of essential oils from plant by products. Molecules 2019, 24, 2941. [CrossRef]

3. Caputo, L.; Nazzaro, F.; Souza, L.F.; Aliberti, L.; De Martino, L.; Fratianni, F.; Coppola, R.; De Feo, V. Laurus nobilis: Composition of essential oil and its biological activities. Molecules 2017, 22, 930. [CrossRef] [PubMed]

4. Nazzaro, F.; Fratianni, F.; De Martino, L.; Coppola, R.; De Feo, V. Effect of essential oils on pathogenic bacteria. Pharmaceuticals 2013, 6, 1451-1474. [CrossRef]

5. Da Porto, C.; Decorti, D.; Kikic, I. Flavour compounds of Lavandula angustifolia L. to use in food manufacturing: Comparison of three different extraction methods. Food Chem. 2009, 112, 1072-1078. [CrossRef]

6. Reverchon, E.; Della Porta, G. Supercritical $\mathrm{CO}_{2}$ extraction and fractionation of Lavender essential oil and waxes. J. Agric. Food Chem. 1995, 43, 1654-1658. [CrossRef]

7. Mantovani, A.L.L.; Vieira, G.P.G.; Cunha, W.R.; Groppo, M.; Santos, R.A.; Rodrigues, V.; Magalhaes, L.G.; Crotti, A.E.M. Chemical composition, antischistosomal and cytotoxic effects of the essential oil of Lavandula angustifolia grown in Southeastern Brazil. Rev. Bras. Farmacogn. 2013, 23, 877-884. [CrossRef]

8. Shellie, R.; Mondello, L.; Marriott, P.; Dugo, G. Characterisation of lavender essential oils by using gas chromatographymass spectrometry with correlation of linear retention indices and comparison with comprehensive two-dimensional gas chromatography. J. Chromatogr. A 2002, 970, 225-234. [CrossRef]

9. Cong, Y.; Abulizi, P.; Zhi, L.; Wang, X. Chemical composition of the essential oil of Lavandula angustifolia from Xinjiang, China. Chem. Nat. Compd. 2008, 44, 810-815. [CrossRef]

10. Daferera, D.J.; Ziogas, B.N.; Polissou, M.G. GC-MS analysis of essential oils from some Greek aromatic plants and their fungitoxicity on Penicillium digitatum. J. Agric. Food Chem. 2000, 48, 2576-2581. [CrossRef] [PubMed]

11. D'Auria, F.D.; Tecca, M.; Strippoli, V.; Salvatore, G.; Battinelli, L.; Mazzanti, G. Antifungal activity of Lavandula Angustifolia essential oil against Candida albicans yeast and mycelial form. Med. Mycol. 2005, 43, 391-396. [CrossRef] [PubMed]

12. Bialon., M.; Krzysko-Lupicka, T.; Nowakowska-Bogdan, E.; Wieczorek, P.P. Chemical composition of two different lavander essential oils and their effect on facial skin microbiota. Molecules 2019, 24, 3270. [CrossRef]

13. Danh, L.T.; Han, L.N.; Triet, N.D.A.; Zhao., J.; Mammuccari, R.; Foster, N. Comparison of chemical composition, antioxidant and antimicrobial activity of lavander (Lavandula angustifolia L.) Essential Oils Extracted by Supercritical $\mathrm{CO}_{2}$, hexane and hydrodistillation. Food Bioproc. Technol. 2013, 6, 3481-3489. [CrossRef]

14. An, M.; Haig, T.; Hatfield, P. On-site sampling and analysis of fragrance from living Lavender (Lavandula angustifolia L.) flowers by solid-phase microextraction coupled to gas chromatography and ion-trap mass spectrometry. J. Chromatogr. A. 2001, 917, 245-250. [CrossRef]

15. Kim, N.S.; Lee, D.D. Comparison of different extraction method for the analysis of fragrance from Lavandula species by gas chromatography-mass spectrometry. J. Chromatogr. A. 2002, 982, 31-47. [CrossRef]

16. Gora, J.; Lis, A. The most valuable oils-Lavender oil. Aromaterapia PTA 1995, 2, 5-11.

17. Mayaud, L.; Carricajo, A.; Zhiri, A.; Aubert, G. Comparison of bacteriostatic and bactericidal activity of 13 essential oils against strains with varying sensitivity to Antibiotics. Lett. Appl. Microbiol. 2008, 47, 167-173. [CrossRef]

18. Stanojević, L.; Stanković, M.; Cakić, M.; Nikolić, V.; Nikolić, L.; Ilić, D.; Radulović, N. The effect of hydrodistillation techniques on yield, kinetics, composition and antimicrobial activity of essential oils from flowers of Lavandula officinalis L. Hem. Ind. 2011, 65, 455-463. [CrossRef]

19. Hanamanthagouda, M.A.; Kakkalameli, S.B.; Naik, P.M.; Nagella, P.; Seetharamareddy, H.R.; Murthy, H.N. Essential oils of Lavandula bipinnata and their antimicrobial activities. Food Chem. 2010, 118, 836-839. [CrossRef]

20. Duval, R.E.; Grare, M.; Demoré, B. Fight against Antimicrobial Resistance: We always need new antibacterials but for right bacteria. Molecules 2019, 24, 3152. [CrossRef] [PubMed] 
21. Braz, V.S.; Melchior, K.; Moreira, C.G. Escherichia coli as a multifaceted pathogenic and versatile bacterium. Front. Cell. Infect. Microbiol. 2020, 10, 548492. [CrossRef] [PubMed]

22. Xie, C.; Huang, C.H.; Vallad, G.E. Mycelial compatibility and pathogenic diversity among Sclerotium rolfsii isolates in southeastern United States. Plant Dis. 2014, 98, 1685-1694. [CrossRef] [PubMed]

23. Hui, L.; He, L.; Lu Huan, L.; XiaoLan, L.; Guo, Z.A. Chemical composition of lavender essential oil and its antioxidant activity and inhibition against rhinitis related bacteria. Afr. J. Microbiol. Res. 2010, 4, 309-313.

24. Lin, C.-W.; Yu, C.-W.; Wu, S.-C.; Yih, K.-H. DPPH free-radical scavenging activity, total phenolic contents and chemical composition analysis of fourty-two kinds of essential oils. J. Food Drug Anal. 2009, 17, 386-395.

25. Donellia, D.; Antonellia, M.; Bellinazzi, C.; Gensini, G.F.; Firenzuoli, F. Effects of lavender on anxiety: A systematic review and meta-analysis. Phytomedicine 2019, 65, 153099. [CrossRef] [PubMed]

26. Barresi, G.; Di Carlo, E.; Trapani, M.R.; Parisi, M.G.; Chille, C.; Mule, M.F.; Cammarata, M.; Palla, F. Marine organisms as source of bioactive molecules applied in restoration projects. Herit. Sci. 2015, 3, 17. [CrossRef]

27. Palla, F.; Bruno, M.; Mercurio, F.; Tantillo, A.; Rotolo, V. Essential oils as natural biocides in conservation of Cultural heritage. Molecules 2020, 25, 730. [CrossRef]

28. Arabhosseini, A.; Huisman, W.; van Boxtel, A.; Müller, J. Long-term effects of drying conditions on the essential oil and color of tarragon leaves duringstorage. J. Food Eng. 2007, 79, 561-566. [CrossRef]

29. Argyropoulos, D.; Müller, J. Changes of essential oil content and composition during convective drying of lemon balm (Melissa officinalis L.). Ind. Crops Prod. 2014, 52, 118-124. [CrossRef]

30. Dušková, E.; Dušek, K.; Indrák, P.; Smékalová, K. Postharvest changes in essential oil content and quality of lavender flowers. Ind. Crop. Prod. 2016, 79, 225-231. [CrossRef]

31. Adams, R.P. Identification of Essential Oil Components by Gas Chromatography/Mass Spectrometry, 4th ed.; Allured Publishing Co.: Carol Stream, IL, USA, 2007; ISBN 978-1932633214.

32. Ärje, J.; Choi, K.P.; Divino, F.; Meissner, K.; Kärkkäinen, S. Understanding the statistical properties of the percent model affinity index can improve biomonitoring related decision making. Stoch. Environ. Res. Risk Assess. 2016, 30, 1981-2008. [CrossRef]

33. Karthikeyan, V.; Sankaralingam, A.; Nakkeeran, S. Management of groundnut root rot with biocontrol agents and organic amendments. Arch. Phytopathol. Plant Protect. 2006, 39, 215-223. [CrossRef]

34. Falasca, A.; Caprari, C.; De Felice, V.; Fortini, P.; Saviano, G.; Zollo, F.; Iorizzi, M. GC-MS analysis of the essential oils of Juniperus communis L. berries growing wild in the Molise region: Seasonal variability and in vitro antifungal activity. Biochem. Syst. Ecol. 2016, 69, 166-175. [CrossRef]

35. Wavare, S.H.; Gade, R.M.; Shitole, A.V. Effect of plant extracts, bio agents and fungicides against Sclerotium rolfsii causing collar rot in chickpea. Indian J. Pharm. Sci. 2017, 79, 513-520. [CrossRef]

36. Esteves Cardia, G.F.; Silva-Filho, S.E.; Silva, E.L.; Uchida, N.S.; Cavalcante, H.A.O.; Cassarotti, L.L.; Cocco Salvadego, V.E.; Spironello, R.A.; Bersani-Amado, C.A.; Nakamura Cuman, R.K. Effect of lavender (Lavandula angustifolia) essential oil on acute inflammatory response. Evid. Based Complementary Altern. Med. 2018, 2018, 10. [CrossRef]

37. Carson, C.F.; Riley, T.V. Antimicrobial activity of the major components of the essential oil of Melaleuca alternifolia. J. Appl. Bacteriol. 1995, 78, 264-269. [CrossRef]

38. Guimarães, A.C.; Meireles, L.M.; Lemos, M.F.; Guimarães, M.C.C.; Endringer, D.C.; Fronza, M.; Scherer, R. Antibacterial activity of terpenes and terpenoids present in essential oils. Molecules 2019, 24, 2471. [CrossRef] [PubMed]

39. Jing, L.; Lei, Z.; Li, L.; Xie, R.; Xi, W.; Guan, Y.; Sumner, L.W.; Zhou, Z. Antifungal activity of citrus essential oils. J. Agric. Food Chem. 2014, 62, 3011-3013. [CrossRef] [PubMed]

40. Okoh, S.O.; Asekun, O.T.; Familoni, O.B.; Afolayan, A.J. Antioxidant and free radical scavenging capacity of seed and shell essential oils extracted from Abrus precatorius (L). Antioxidants 2014, 3, 278-287. [CrossRef]

41. Inouye, S.; Shigeru, A.; Hideyo, Y.; Matsumi, A. Comparative study of antimicrobial and cytotoxic effects of selected essential oils by gaseous and solution contacts. Int. J. Aromather. 2003, 13, 33-41. [CrossRef]

42. Bakkali, F.; Averbeck, S.; Averbeck, D.; Idaomar, M. Biological effects of essential oils-A review. Food Chem. Toxicol. 2008, 46, 446-475. [CrossRef]

43. Sailer, R.; Berger, T.; Reichling, J.; Harkenthal, M. Pharmaceutical and medicinal aspects of Australian tea tree oil. Phytomedicine 1998, 5, 489-495. [CrossRef]

44. Usachev, E.; Pyankov, O.V.; Usacheva, O.V.; Agranovski, I.E. Antiviral activity of tea tree and eucalyptus oil aerosol and vapour. J. Aerosol. Sci. 2013, 59, 22-30. [CrossRef]

45. Pyankov, O.V.; Usachev, E.V.; Pyankova, O.; Agranovski, I.E. Inactivation of airborne influenza virus by tea tree and eucalyptus oils. Aerosol. Sci. Technol. 2012, 46, 1296-1302. [CrossRef]

46. Angulo-Milhema, S.; Verriele, M.; Nicolas, M.; Thevenet, F. Indoor use of essential oils: Emission rates, exposure time and impact on air quality. Atmos. Environ. 2021, 244, 117963. [CrossRef]

47. Aycock, R. Stem Rot and Other Diseases Caused by Sclerotium Rolfsii or the Status of Rolfs' Fungus after 70 Years; North Carolina State University: Raleigh, NC, USA, 1966; pp. 132-202.

48. Farr, D.F.; Bills, G.F.; Chamuris, G.P.; Rossaman, A.Y. Fungi on Plants and Plant Products in the United States; VIII APS Press: St. Paul, MN, USA; p. 1989, ISBN 978-0890540992.

49. Rajput, V.A.; Konde, S.A.; Thakur, M.R. Evaluation of bioagents against chickpea wilt complex. J. Soils Crop. 2010, 20, 155-158. 
50. Lucini, E.I.; Zunino, M.P.; Lopez, M.L.; Zygadlo, J.A. Effect of monoterpenes on lipid composition and sclerotial development of Sclerotium cepivorum Berk. J. Phytopathol. 2006, 154, 441-446. [CrossRef]

51. Sharma, N.; Tripathi, A. Effects of Citrus sinensis (L.) Osbeck epicarp essential oil on growth and morphogenesis of Aspergillus niger (L.) Van Tieghem. Microbiol. Res. 2008, 163, 337-344. [CrossRef] [PubMed]

52. Council of Europe. European Pharmacopoeia, 5th ed.; Council of Europe: Strasbourg, France, 2004; Volume I, p. 217.

53. Kovats, E. Gas Chromatographic Characterization of Organic Substances in the Retention Index System. In Advances in Chromatography; Giddings, J.C., Keller, R.A., Eds.; Marcel Dekker, Inc.: New York, NY, USA, 1965; Volume I, pp. $229-247$.

54. Van den Dool, H.; Kratz, P.D. A generalization of the retention index system including linear temperature programmed gas-liquid partition chromatography. J. Chromatogr. A. 1963, 11, 463-471. [CrossRef]

55. NIST/EPA/NIH. Mass Spectral Library; National Institute of Standard and Technology: Gaithersburg, MD, USA, 2005.

56. McLafferty, F.W. Wiley Registry of Mass Spectral Data, with NIST Spectral Data CD Rom, 7th ed.; John Wiley \& Sons: New York, NY, USA, 2000.

57. Grob, R.L.; Kaiser, M.A. Qualitative and quantitative analysis by gas chromatography. In Modern Practice of Gas Chromatography; Grob, B., Ed.; John Wiley \& Sons: New York, NY, USA, 2004; ISBN 0471229830.

58. Youngman, P.; Perkins, J.B.; Losick, R. A novel method for the rapid cloning in Escherichia coli of Bacillus subtilis chromosomal DNA adjacent to Tn917 insertions. Mol. Gen. Genet. 1984, 195, 424-433. [CrossRef] [PubMed]

59. Sambrook, J.; Fritsch, E.R.; Maniatis, T. Molecular Cloning: A Laboratory Manual, 2nd ed.; Cold Spring Harbor Laboratory Press: Cold Spring Harbor, NY, USA, 1989.

60. Bergey, D.H.; Holt, J.G. Bergey's Manual of Determinative Bacteriology, 9th ed.; Lippincott Williams and Wilkins: Philadelphia, PA, USA, 2000.

61. Ranalli, G.; Zanardini, E.; Rampazzi, L.; Corti, C.; Andreotti, A.; Colombini, M.P.; Bosch-Roig, P.; Lustrato, G.; Giantomassi, C.; Zari, D.; et al. Onsite advanced biocleaning system for historical wall paintings using new agar-gauze bacteria gel. J. Appl. Microbiol. 2019, 126, 1785-1796. [CrossRef] [PubMed]

62. Ranalli, G.; Zanardini, E. Biocleaning on Cultural Heritage: New frontiers of microbial biotechnologies. J. Appl. Microbiol. 2021, 31, 583-603. [CrossRef] [PubMed] 